\title{
East Tennessee State University
}

\section{Digital Commons@ East Tennessee State University}

\section{A Comparative Study to Calculate Hydraulic Conductivity in Ultisols on an East Tennessee Hillslope}

Sydney A. Lawson

East Tennessee State University

Follow this and additional works at: https://dc.etsu.edu/honors

Part of the Geology Commons

\section{Recommended Citation}

Lawson, Sydney A., "A Comparative Study to Calculate Hydraulic Conductivity in Ultisols on an East Tennessee Hillslope" (2015).

Undergraduate Honors Theses. Paper 420. https://dc.etsu.edu/honors/420

This Honors Thesis - Withheld is brought to you for free and open access by the Student Works at Digital Commons @ East Tennessee State University. It has been accepted for inclusion in Undergraduate Honors Theses by an authorized administrator of Digital Commons @ East Tennessee State

University. For more information, please contact digilib@etsu.edu. 


\section{"A Comparative Study to Calculate Hydraulic Conductivity in Ultisols on an East Tennessee Hillslope"}

By:

Sydney A. Lawson

An Undergraduate Thesis Submitted in Partial Fulfillment

of the Requirements for the

University Honors Scholars Program

Honors College

and the

Department of Geosciences

College of Arts \& Sciences

East Tennessee State University
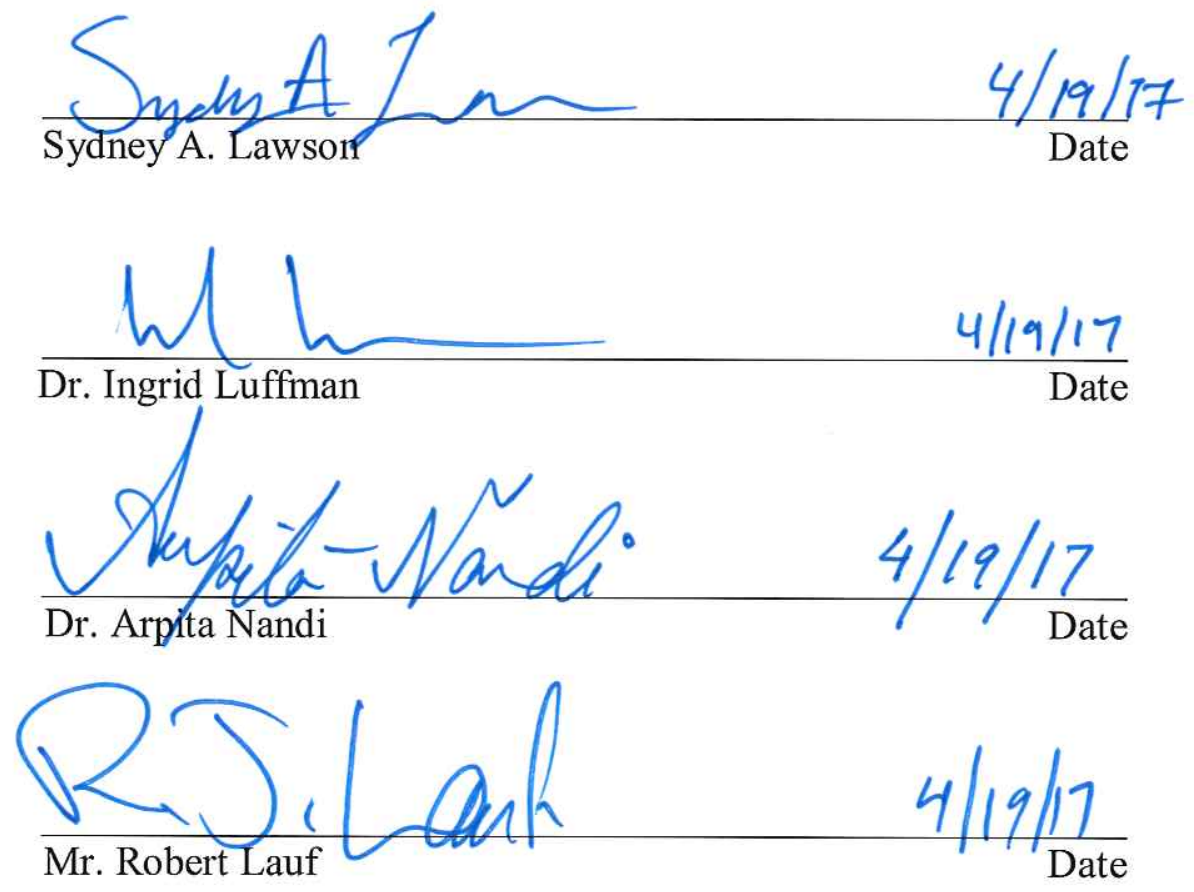


\section{Table of Contents}

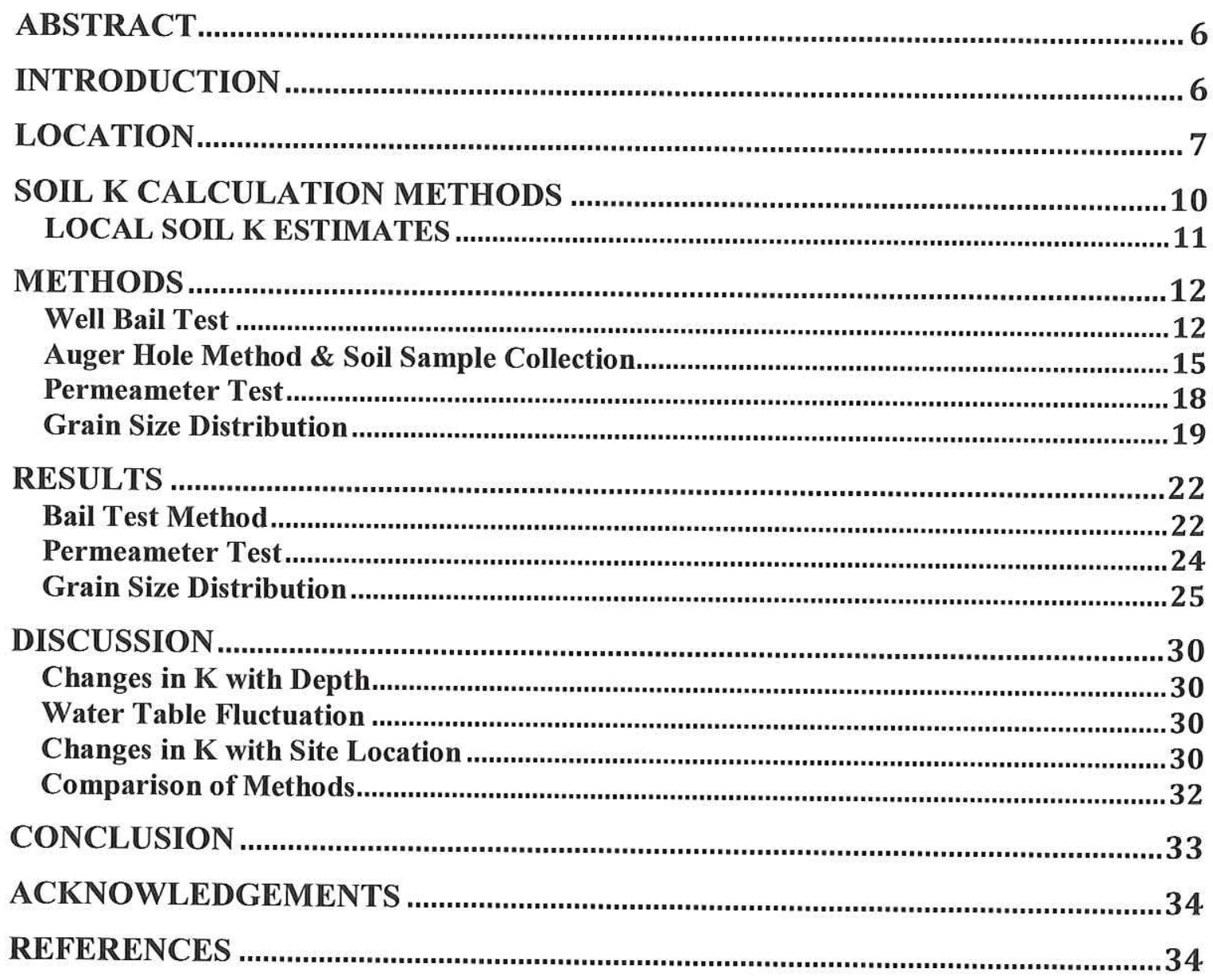




\section{List of Figures}

Figure 1 - Site map of the study area. The Well Site and Sites $1 \& 2$ are located to the southeast. Sites 3, 4, $\& 5$ are located in the east along a floodplain near a blue line stream (a tributary of Kendrick Creek, marked in blue).

Figure 2 - Soils map of the study area. $\mathrm{BmC}$ is a Bellamy loam, 5 to 12 percent slopes. $\mathrm{CeC} 2$ is the Collegedale-Etowah complex, 5 to12 percent slopes, eroded. $\mathrm{CeD} 3$ is the Collegedale-Etowah complex, 20 to 35 percent slopes, severely eroded. $\mathrm{Dz}$ is dumps, landfills. $\mathrm{GnB}$ is the Greendale silt loam, 0 to 6 percent slopes, rarely flooded. $\mathrm{LeC} 2$ is the leadville silt loam, 5 to 12 percent slopes, eroded. MoD is the Montevallo Channery silt loam, 12 to 20 percent slopes. MoF is the Montevallo Channery silt loam, 35 to 50 percent slopes. St is the Steadman silt loam, 0 to 12 percent slopes, occasionally flooded. TbD2 is the Talbott-Rock outcrop-Bradyville complex, 12 to 20 percent slopes, eroded. (USDA, Soil Survey 2016).

Figure 3 - During the study, the local water table lowered with masked recovery of the well. A) Original groundwater lever, B) Well water level after bailing, C) Well level at the end of the recovery period, and D) Well level at the end of the test.

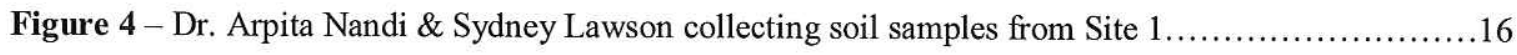

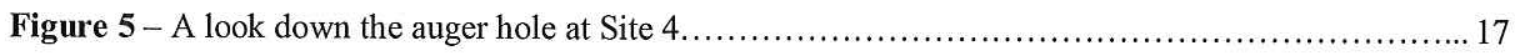

Figure 6 - Sydney Lawson keeping a consistent water level in the constant head permeameter test........19

Figure 7 - All 8 sieves stacked on top of one another (left) and in the mechanical shaker (right)..........20

Figure 8 - Well recovered as expected from $t=0$ to $t=79200$ ( 22 hours) when recovery ceased............ 22

Figure 9 - Water depth initially decreased during the recovery phase (0 to 22 hours). Later, water depth increased due to a local drop in the water table. Well recovery data, $\Delta \mathrm{h}_{\mathrm{t}}$ are included for comparison.

Figure 10 - Detrended water level results showing the corrected drawdown with the linear and exponential trend lines for partition 1 (in purple) and partition 2 (in blue), the original data (in green) are shown for comparison

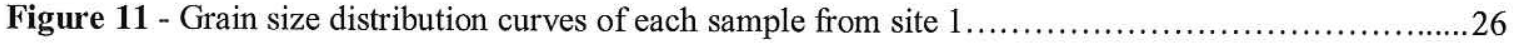

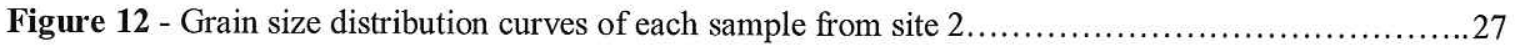

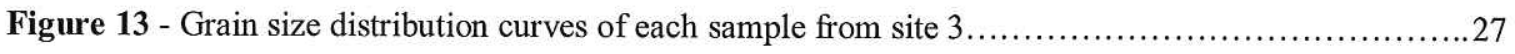

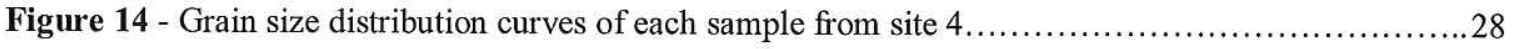

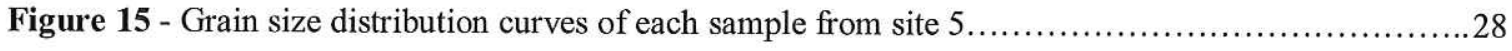

Figure 16 - Map of Tennessee showing the severity of the drought on May 17, 2016 (top) and October 25, 2016 (bottom); Washington County is outlined in a black box...................................... 31

Figure 17 - Local drought severity for Washington County, TN shown by month indicates abnormally dry to moderate drought conditions during the well bail test study period (outlined with the dashed box). 


\section{List of Tables}

Table 1 - Summary of $\mathrm{t}_{37}$ estimates found from linear and exponential equations....................................24

Table 2 - Summary of hydraulic conductivity estimates from all bail test scenarios. ..................................24

Table 3 - Hydraulic Conductivity estimates calculated using permeameter method..................................25

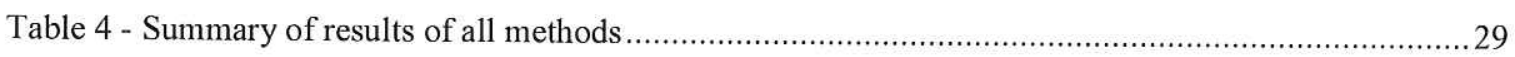




\section{ABSTRACT}

This study compares four different methods to measure hydraulic conductivity (K) at two sites on the East Tennessee State University Valleybrook Campus. It compares the $\mathrm{K}$ values to each other, to the different $\mathrm{K}$ values between the two sites, and to United States Department of Agriculture (USDA) K values. Two field methods, Well Bail Test and Auger Hole Test, and two lab methods, Constant Head Permeameter Test and Grain Size Distribution Test (GSD), were performed on the clay rich Ultisol soils on an East Tennessee hillslope in the Valley and Ridge Physiographic Province. One site was located close to a monitoring well and the other on the floodplain of an existing stream. The Hazen, Alyamani \& Sen, and Slichter methods were used to compute K from the GSD Test. The Alyamani \& Sen, Slichter, and permeameter methods produced similar K values ranging from $9.52 \times 10^{-6}$ to $1.25 \times 10^{-3} \mathrm{~cm} / \mathrm{sec}$. These are similar to the USDA K values ranging from $9.17 \times 10^{4}$ to $2.82 \times 10^{-4} \mathrm{~cm} / \mathrm{sec}$. The Hazen method overestimated $\mathrm{K}$ and ranged from $8.10 \times 10^{-3}$ to $1.09 \times 10^{-1} \mathrm{~cm} / \mathrm{sec}$. The Well Bail Test yielded a lower $\mathrm{K}$ value (ranging from $8.16 \times 10^{-9}$ to $1.19 \times 10^{-8} \mathrm{~cm} / \mathrm{sec}$ ) than the USDA values as expected for water flow in deeper soil horizons at a depth of 8.50 meters. Comparing these values helped to better understand the difference between various methods to compute the hydraulic conductivity.

\section{INTRODUCTION}

Hydraulic conductivity $(\mathrm{K})$ is a measure of the ease with which a medium transmits water; the higher the $\mathrm{K}$ value, the easier the water is transmitted (Hvorslev, 1951). Hydraulic conductivity influences many hydrological processes including: water 
infiltration, soil water erosion, groundwater recharge, and pollutant transport. Studying the flow of groundwater in soils at the East Tennessee State University Valleybrook Research Campus will help to fill gaps in knowledge of groundwater flow in the Valley and Ridge Physiographic Province. A complete well test has not been performed at the site, however, previously two partial well tests were conducted at the site generating two $\mathrm{K}$ estimates of $1.30 \times 10^{-6} \mathrm{~cm} / \mathrm{sec}$ and $2.60 \times 10^{-6} \mathrm{~cm} / \mathrm{sec}$. A complete long-term test will reduce uncertainty inherent in the partial tests and provide a more reliable estimate for $\mathrm{K}$.

In a separate research study at this site, soil $\mathrm{K}$ was calculated (with $\mathrm{K}$ values ranging from $5.41 \times 10^{-2}$ to $1.57 \times 10^{-3} \mathrm{~cm} /$ day) for areas of non-gully erosion at the same site using the empirical Grain Size Distribution (GSD) method (Nandi and Luffman, 2012). The present study will estimate $\mathrm{K}$ values using four different methods: the Well Bail Test, the Auger Hole Method, the Constant-Head Permeameter Test, and Grain Size Distribution Method. The goal of this study is to quantify variability between the four methods and compare how $\mathrm{K}$ values differ between the well site and the floodplain soils near a blue line stream on site.

\section{LOCATION}

The study area is located on the East Tennessee State University Valleybrook Campus (N 36 25' 27' W 082 32' 34") near Kingsport, TN in the Valley and Ridge Physiographic Province (Fig. 1). 


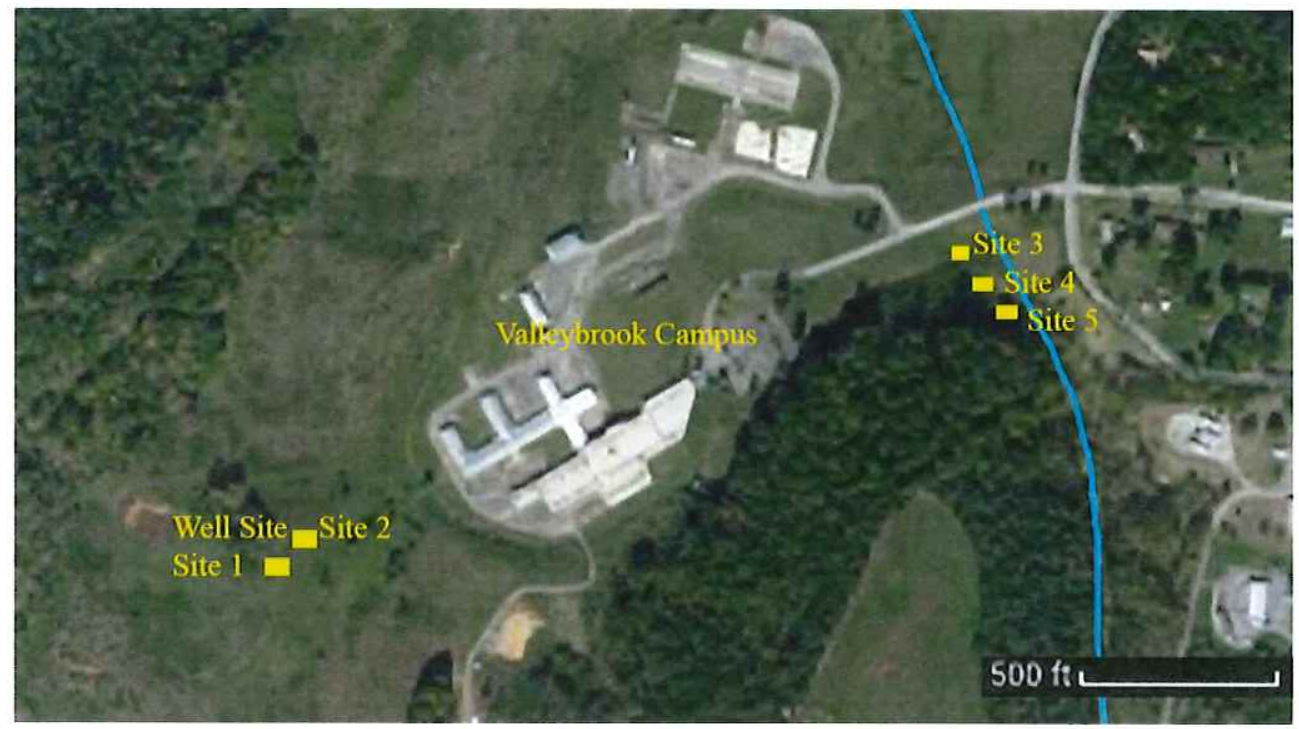

Figure 1 - Site map of the study area. The Well Site and Sites $1 \& 2$ are located to the southeast. Sites $3,4, \& 5$ are located in the east along a floodplain near a blue line stream (a tributary of Kendrick Creek, marked in blue).

The valley and ridges trend northeast to southwest; the ridges are underlain by resistant shale (Nolichucky Formation) and the valleys are dominated by limestone, dolostone, and chert (Maynardville Formation) (Rodgers, 1953; King \& Ferguson, 1960; Hardeman, 1966). These rocks weather to the fine-grained silty and clayey Ultisols of the Collegedale-Etowah complex (CeD3), the Bellamy loam (BmC), and the Steadman silt loam (St) (USDA Soil Survey 2016). The soils in the study area (Fig. 2) fall within the Hydrological Soils Group C, with at least one of the following characteristics: the soils have a slow infiltration rate when thoroughly wet, a low K layer impedes the downward movement of water, or soils have a moderately fine or fine texture (USDA Soil Survey, 2016). Group $\mathrm{C}$ soils have a slow rate of water transmission and $\mathrm{K}$ values in these soils range from $8.03 \times 10^{-4}$ to $2.82 \times 10^{-4} \mathrm{~cm} / \mathrm{sec}$ (USDA Soil Survey, 2016). 


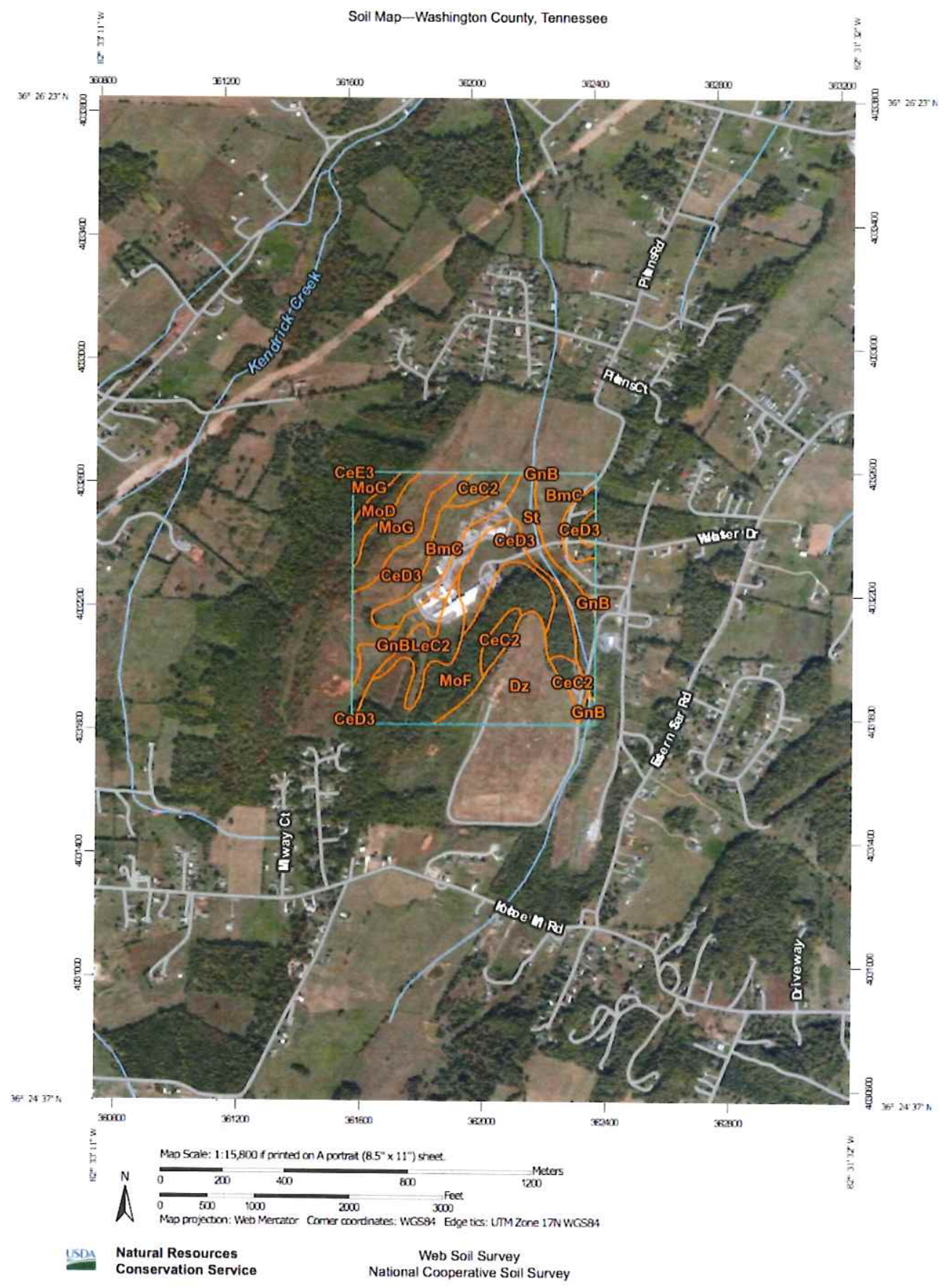

Figure 2 - Soils map of the study area. BmC is a Bellamy loam, 5 to 12 percent slopes. CeC2 is the CollegedaleEtowah complex, 5 to12 percent slopes, eroded. CeD3 is the Collegedale-Etowah complex, 20 to 35 percent slopes, severely eroded. Dz is dumps, landfills. GnB is the Greendale silt loam, 0 to 6 percent slopes, rarely flooded. LeC2 is the Leadville silt loam, 5 to 12 percent slopes, eroded. MoD is the Montevallo Channery silt loam, 12 to 20 percent slopes. MoF is the Montevallo Channery silt loam, 35 to 50 percent slopes. St is the Steadman silt loam, 0 to 12 percent slopes, occasionally flooded. TbD2 is the Talbott-Rock outcrop-Bradyville complex, 12 to 20 percent slopes, eroded. (USDA, Soil Survey 2016) 
The humid subtropical climate (Cfa Köppen climate classification) gives rise to hot summers, mild winters, and year-round precipitation. The average temperature during the study timeframe (May 22 to October 13,2016) was $24^{\circ} \mathrm{C}$ and the average monthly precipitation was $9.88 \mathrm{~cm}$. The average annual temperature is $15^{\circ} \mathrm{C}$ and the average annual precipitation is $136 \mathrm{~cm}$. Land cover at the site is mainly pasture and forest land with trees covering the ridgeline. The area surrounding the site is developed residential land and a landfill is located to the southeast. A tributary of Kendrick Creek runs northeast along the campus, near the entrance to the facility.

\section{SOIL K CALCULATION METHODS}

Soil K may be calculated by several different methods. The well bail test method is common and can be done fairly easily if a well or borehole is available. This method involves removing a measured volume of groundwater from the well and then recording the groundwater depth as it recharges. The pumping and slug test methods are similar ways of measuring $\mathrm{K}$. The pumping test involves pumping water from a well at a steady state for at least a day, and the well is monitored as it recharges. Slug and bail tests are similar to the pumping test, but involve the rapid removal or addition of water or insertion of a solid sand-fill bailer (slug). Water levels are monitored as the well recovers back to the static level (Cheong et al. (2008), Svensson (2014), Takounjou, Fanton, Ngoupayou, \& Nkamdjou (2012), and Vienken \& Dietrich (2005)).

The auger hole method is not as widely used as other methods because of problems encountering shallow bedrock. A hole is dug until the water table is reached and the groundwater flows into hole. A predetermined amount of groundwater is then 
removed from the hole and the time necessary for the groundwater to recharge to its original level is measured (Barau and Hoffman (2007)).

The permeameter test measures soil $\mathrm{K}$ by placing the soil sample in a closed cell and running water through the sample; the amount of time necessary for a known volume of water to run through the sample is used to calculate soil K. Svensson (2014) used an open-air permeameter and because of the very fine grains in her samples, found little to no flow when performing the tests. West, Abreu, and Bishop (2007) performed the permeameter test in the field while testing wastewater. The results provided higher $\mathrm{K}$ values in samples with low clay content and lower $\mathrm{K}$ values on samples with high clay content.

The grain size distribution method is commonly used because it is easy to perform with readily available lab equipment. The method tests soil samples by separating them by grain size and determining the percentage of each grain size present in the sample. Cheong et al. (2008), Rosas, Jadoon, \& Missimer (2014), Svensson (2014), Takounjou et al. (2012), and Vienken and Dietrich (2005) used grain size distribution equations to calculate soil K. J. Rosas, Jadoon, \& Missimer (2014) and Takounjou, Fantong, Ngoupayou, \& Nkamdjou (2012) used the Slichter and Alyamani \& Sen equation and found that results correlated well with other empirical methods of calculating soil $\mathrm{K}$. These researchers also used the Hazen Equation and found it to slightly overestimate soil K.

\section{LOCAL SOIL K ESTIMATES}

Nandi \& Luffman (2012) calculated the hydraulic conductivity of soil in the study area using the constant head permeameter test on four cores collected from the erosion 
site and a site nearby where no indication of past erosion was visible. Hydraulic conductivity estimates for the non-eroded site for soil horizon $\mathrm{O}$ were $9.13 \times 10^{-3}$ $\mathrm{cm} / \mathrm{sec}$, for soil horizon A were $9.88 \times 10^{-3} \mathrm{~cm} / \mathrm{sec}$, for soil horizon B were $1.82 \times$ $10^{-2} \mathrm{~cm} / \mathrm{sec}$, and for soil horizon $\mathrm{C}$ were $6.26 \times 10^{-2} \mathrm{~cm} / \mathrm{sec}$. For the eroded site, $\mathrm{K}$ estimates for soil horizon A were $1.08 \times 10^{-2} \mathrm{~cm} / \mathrm{sec}$, for soil horizon B were $9.49 \times$ $10^{-3} \mathrm{~cm} / \mathrm{sec}$, and for soil horizon $\mathrm{C}$ were $9.95 \times 10^{-3} \mathrm{~cm} / \mathrm{sec}$.

In 2013 a partial well bail test at the location was performed within a one-hour time frame, and extrapolated results found a $\mathrm{K}$ value of $1.30 \times 10^{-6} \mathrm{~cm} / \mathrm{sec}$. The partial well test was repeated in 2015 within a two-hour time frame and extrapolated results found a $\mathrm{K}$ value of $2.60 \times 10^{-6} \mathrm{~cm} / \mathrm{sec}$. USDA $\mathrm{K}$ values of the $\mathrm{BmC}$ soil (near sites 1 and 2, Fig. 1) have a $\mathrm{K}$ value of $7.84 \times 10^{-4} \mathrm{~cm} / \mathrm{sec}$, the CeD3 soil (near sites $1 \& 2$, Fig. 1) have a K value of $2.82 \times 10^{-4} \mathrm{~cm} / \mathrm{sec}$, and the St soil (near sites 3, 4, and 5, Fig. 1) have a $\mathrm{K}$ value of $8.29 \times 10^{-4} \mathrm{~cm} / \mathrm{sec}$ (USDA Soil Survey, 2016) (CeD3 soil located near well and stream).

\section{METHODS}

Four methods were selected to compare the different K estimates at five sites (Fig. 1) to the reported USDA K values. Most of the equipment to perform the field and lab tests was available from the Hydrology Lab and Soils Labs at the ETSU Department of Geosciences making it ideal to use these methods over others.

\section{Well Bail Test}

The Well Bail Test was conducted from May 22 to October 13, 2016. The Hvorslev Method (Hvorslev, 1951) was chosen because the well at the site is a single 
borehole and the length of the well screen is unknown. The area's top-most aquifer system is unconfined and the thickness is unknown. The Hvorslev Method is the most appropriate method for these conditions. This method assumes: 1) the entire screen length of the well is beneath the water table, 2) water is added/removed instantaneously, 3) the well diameter is small relative to the screened length, and 4) the hydraulic conductivity of the aquifer in the vicinity of the well is representative of the entire aquifer.

Well depth was measured from the top of the well casing to the bottom of the well using a weight attached to a rope. The well's diameter and length were measured with a measuring tape and depth to water was measured with a Solinist 101 \#366 model water level meter (Fig. 3A). Next, 6.6 L of water was bailed in two successive bails. The depth of the static water level was measured with the water level meter immediately after bailing, and at thirty-second intervals for the first three minutes (Fig. 3B). The time interval was lengthened as the well's recharge rate slowed from 30 seconds, to one minute, to two minutes, and so on until it was recorded on a biweekly schedule.

A local drop in the water level was discovered after the first 22 hours (Fig. 3C). To correct for this local drop in the water table (Fig. 3), the data were detrended by modeling the local water table drop with a linear regression model and using the slope to calculate a corrected drawdown $\left(\Delta \mathrm{h}_{\mathrm{t}}\right)$. More specifically, the data were partitioned into early data (while the well was recovering) and late data (when recovery stopped and reversed) and the late data were modeled using linear regression. Once completed, the raw data were detrended using the slope of the late data to account for the lowering of the groundwater level in the region. 


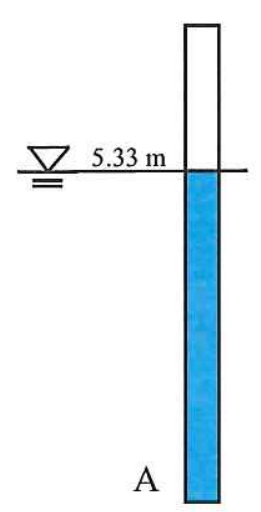

Water level before bailing $($ time $=0 \mathrm{sec})$
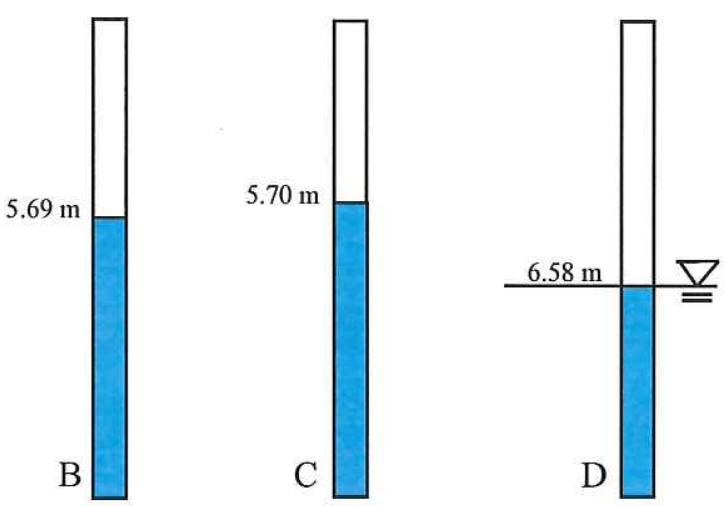

Water level Water level when Water level at end immediately recovery ceased of recording after bailing (time $=22$ hours) $\quad($ time $=116$ days) $($ time $=30 \mathrm{sec})$

Figure 3 - During the study, the local water table lowered with masked recovery of the well. A) Water level before bailing (time = 0), B) Water level immediately after bailing (time $=30 \mathrm{sec})$, C) Water level when recovery ceased (time $=22$ hours), and D) Water level at end of recording (time $=116$ days).

The data were partitioned into two groups due to a short-term fluctuation in water levels at the fourth day $(t=331,200 \mathrm{sec})$ and recovery curves were modeled for each partition using linear and exponential models. Next, $\mathrm{t}_{37}$ (time it takes for the well's water level to recover to $37 \%$ of static level) was calculated using equations extrapolated from the linear and exponential models. K was calculated for two separate assumptions: 1) the well was screened the entire length and 2) the well was screened only from the static water level down. In total, eight estimates for $\mathrm{K}$ were calculated; four $\mathrm{K}$ estimates (two estimates using partition 1 and two estimates using partition 2) assumed the well was screened the entire length and four $\mathrm{K}$ estimates (two estimates using partition 1 and two estimates using partition 2) assumed the well was only screened from the static water level down.

The Hvorslev equation (Hvorslev, 1951) was used to calculate the hydraulic conductivity (K): 


$$
K=\frac{r^{2} \ln \left(\frac{L}{R}\right)}{2 L t_{37}}
$$

where $\mathrm{K}$ = hydraulic conductivity, $\mathrm{R}$ = radius of the well screen, $\mathrm{r}=$ radius of well casing, $\mathrm{t}_{37}=$ time it takes for the well's water level to recover to $37 \%$ of static level, and $\mathrm{L}=$ screened length of the well.

\section{Auger Hole Method \& Soil Sample Collection}

The Auger Hole method was chosen because it is easy to perform and does not require any heavy machinery. As long as the water table is close enough to the surface and bedrock is far enough from the surface, it can be performed. A three-inch auger was used to core five holes, two adjacent to the well and three on the floodplain of a tributary to Kendrick Creek (Fig. 1). Soil samples obtained during augering were labeled and stored in soil sample bags. Sample depth was measured using a tape measure each time the auger was removed. Site 1 was located 2.06 meters east of the well where 42 samples were collected (Fig. 4). The auger hole at Site 1 was 1.22 meters deep, and the first 12.70 $\mathrm{cm}$ of soil recovered from Site 1 was identified as fill material associated with the well's construction because it differed from nearby surface soil and from deeper soil samples. Therefore, a second hole was augered 6.99 meters from the first hole to provide a more representative sample of the native soil (Site 2, Fig. 1). 


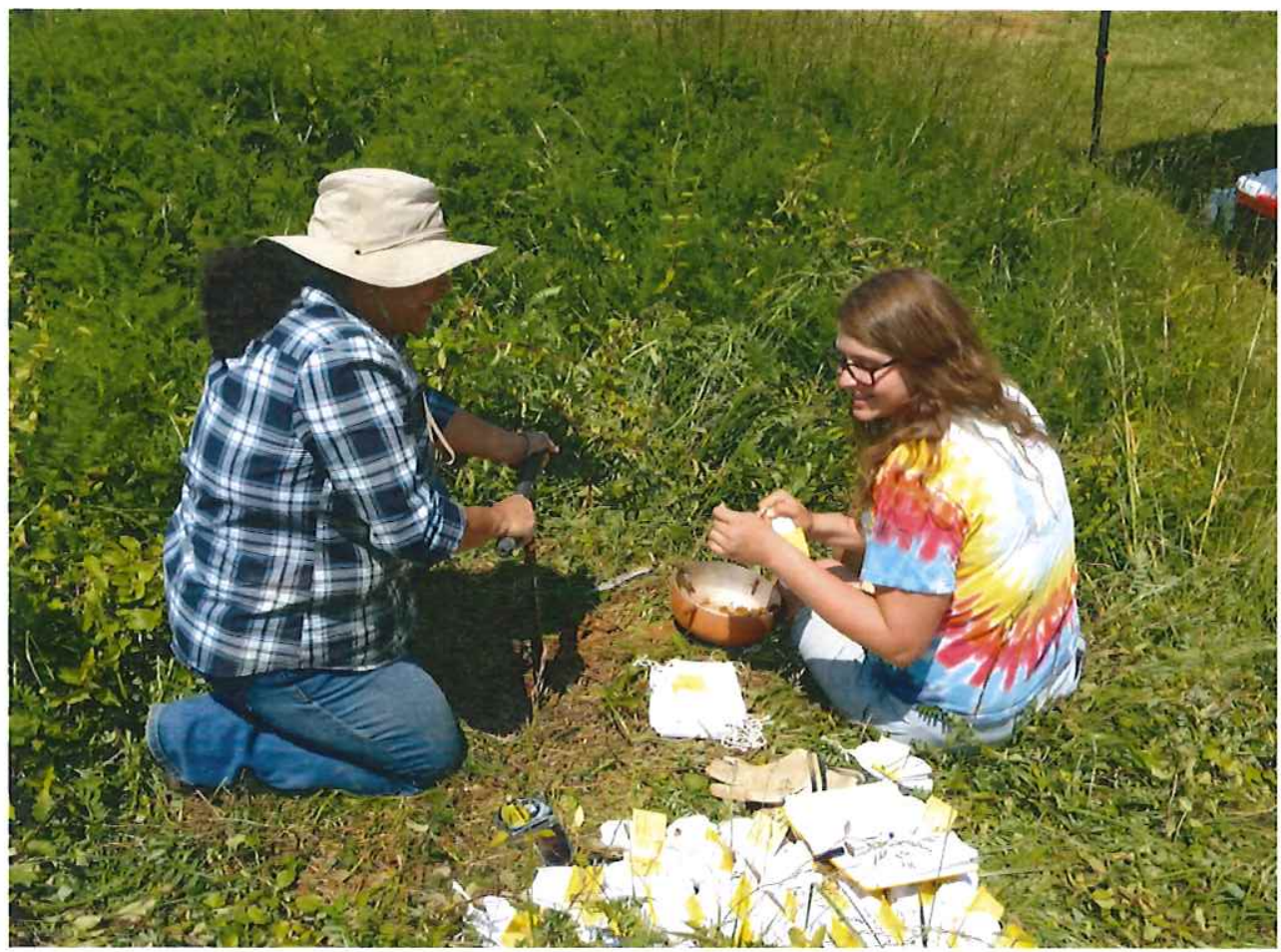

Figure 4 - Dr. Arpita Nandi \& Sydney Lawson collecting soil samples from Site 1.

Additionally, three holes were augered on the floodplain of a tributary of Kendrick Creek (Site 3, 4, and 5). A total of 21 samples were taken from Site 3 (0.76 meters deep, Fig. 5), ten samples were taken from Site 4 (0.38 meters deep), and four samples were taken from Site 5 (0.74 meters deep). Soil samples were bagged and labeled on site and air dried in pans in the ETSU Soils Lab. Once dry, the sample's texture, structure, and consistency were logged using the Field Book for Describing and Sampling Soils, Version 3.0 (Schoeneberger, P.J., D.A. Wysocki, E.C. Benham, and Soil Survey Staff. 2012). Soil color was identified using the Munsell Soil-Color Charts with Genuine Munsell Color Chips (Munsell Color (Firm), (2009)). 


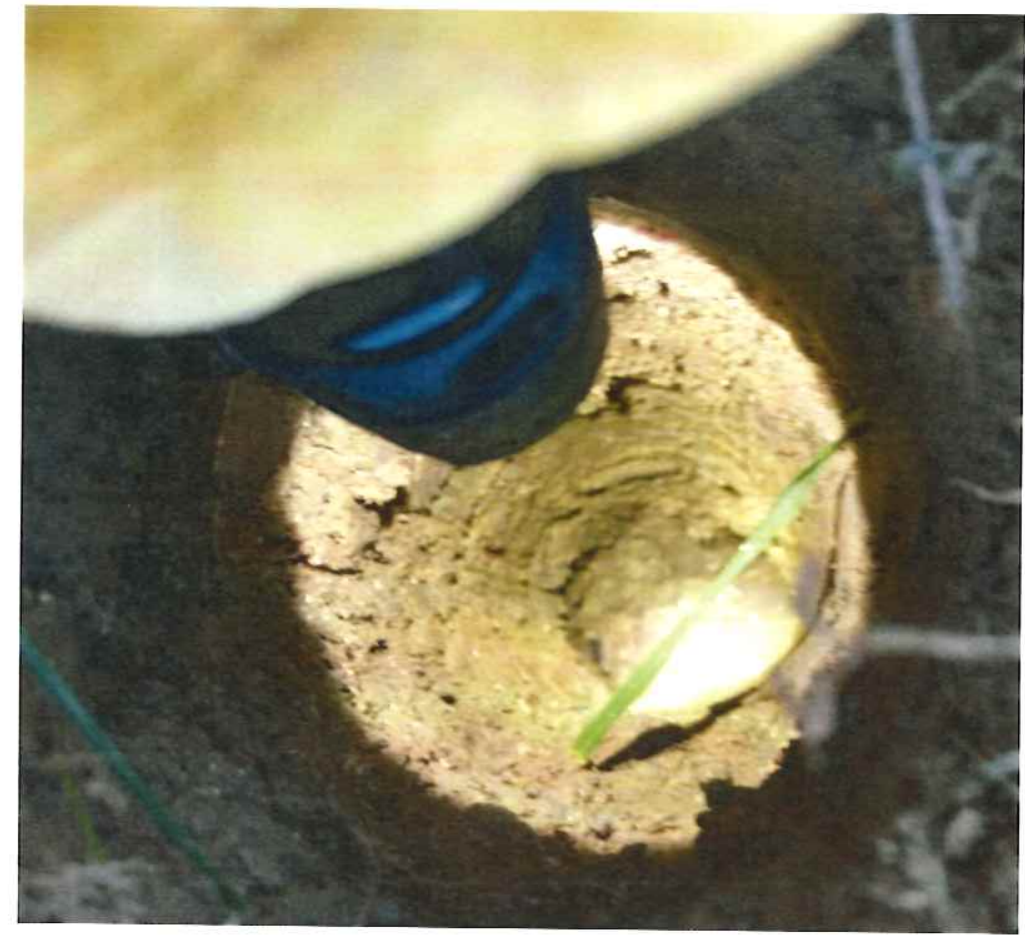

Figure 5 - A look down the auger hole at Site 4.

To accurately calculate $\mathrm{K}$ with the auger hole method, the hole must be dug 60 centimeters below the water table and allowed to fill with water. To begin the test, 40 centimeters of water is bailed out, and the water level is measured every minute until it has risen by $10 \mathrm{~cm}$. The van Beers equation (van Beers, 1983) is then used to calculate K:

$$
K=\frac{4000 r \Delta y}{\left(\frac{H}{r}+20\right)\left(2-\frac{y}{H}\right) y \Delta t}
$$

where $\mathrm{K}$ = hydraulic conductivity, $\mathrm{H}$ = depth of hole below water table, $\Delta \mathrm{y}=$ distance between water table level and average level of water in hole for time interval, $\Delta \mathrm{t}=$ time interval, $\mathrm{r}=$ radius of auger hole, and $\mathrm{S}=$ depth of impermeable layer below the hole.

The water table at Site 1 was too deep and the auger was not long enough to reach the water table. The auger met refusal at Site 3 at a depth of $76.20 \mathrm{~cm}$, at Site 4 at a depth of $38.10 \mathrm{~cm}$, and at Site 5 at a depth of $73.70 \mathrm{~cm}$. 


\section{Permeameter Test}

The Constant Head Permeameter method was chosen because it is a widely used and accepted method. Once the soil samples were dry, large clods were broken down and rocks and grass were removed. Next, a Shelby Tube Permeameter was used to perform the Constant Head Permeameter Test. A porous stone with a piece of filter paper was placed at the base of a 3-inch diameter clear acrylic cell. The cell was then filled with the soil sample in half-inch increments, tamped down, and saturated with water before adding the next layer of soil. The sample was topped with a second piece of filter paper and porous stone. The length of soil in the cell was measured from the base of the soil sample to the top and the difference in hydraulic head was measured from the base of the soil sample to the water line in a water intake funnel suspended above the cell (Fig. 6). Air was flushed from the cell by running water through water lines and the soil cell. Keeping a consistent water level in the funnel (Fig. 6), the time necessary for $50 \mathrm{~mL}$ of water to run through the cell was recorded. 


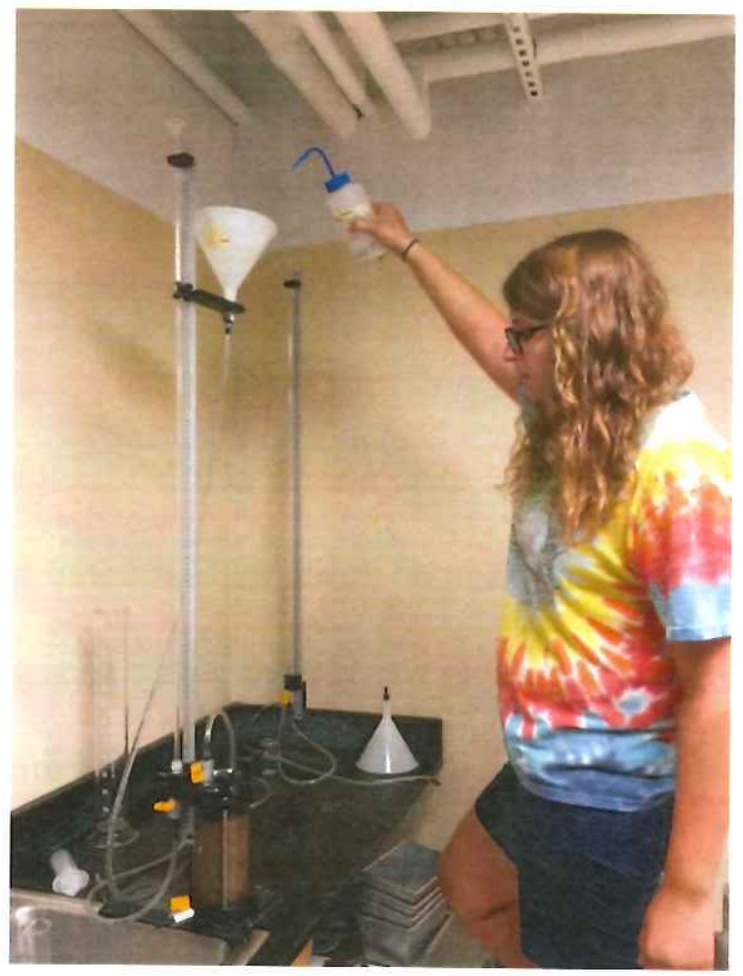

Figure 6 - Sydney Lawson keeping a consistent water level in the constant head permeameter test.

Three replicate tests were completed on each sample and averaged. Darcy's equation (Fetter, 2001) was then used to calculate K:

$$
K=\frac{Q L}{A t h}
$$

where $\mathrm{K}=$ hydraulic conductivity, $\mathrm{Q}=\operatorname{discharge}\left(\mathrm{cm}^{3}\right), \mathrm{A}=$ cross sectional area normal to flow $\left(\mathrm{cm}^{2}\right), \mathrm{L}=$ length $(\mathrm{cm}), \mathrm{t}=$ time (seconds), and $\mathrm{h}=$ difference in hydraulic head (cm).

\section{Grain Size Distribution}

Three equations chosen for the empirical method were the Hazen equation, Alyamani \& Sen equation, and Slichter equation. The Hazen equation is widely accepted and fairly easy to calculate. The Alyamani \& Sen equation is suitable for well-distributed samples and the Slichter equation is suitable for samples with fine particles. All samples 
were sieved to measure grain size distribution. Eight sieves of different sizes were used (stacked from largest to smallest size): 4 (4.75mm), $10(2.0 \mathrm{~mm}), 40(0.425 \mathrm{~mm}), 80$ $(0.18 \mathrm{~mm}), 100(0.15 \mathrm{~mm}), 140(0.106 \mathrm{~mm})$, and $200(0.075)$ (Fig. 7). The uppermost sieve was filled with 500 grams of soil from each sample and the sieve stack was vibrated using a mechanical shaker for ten minutes.

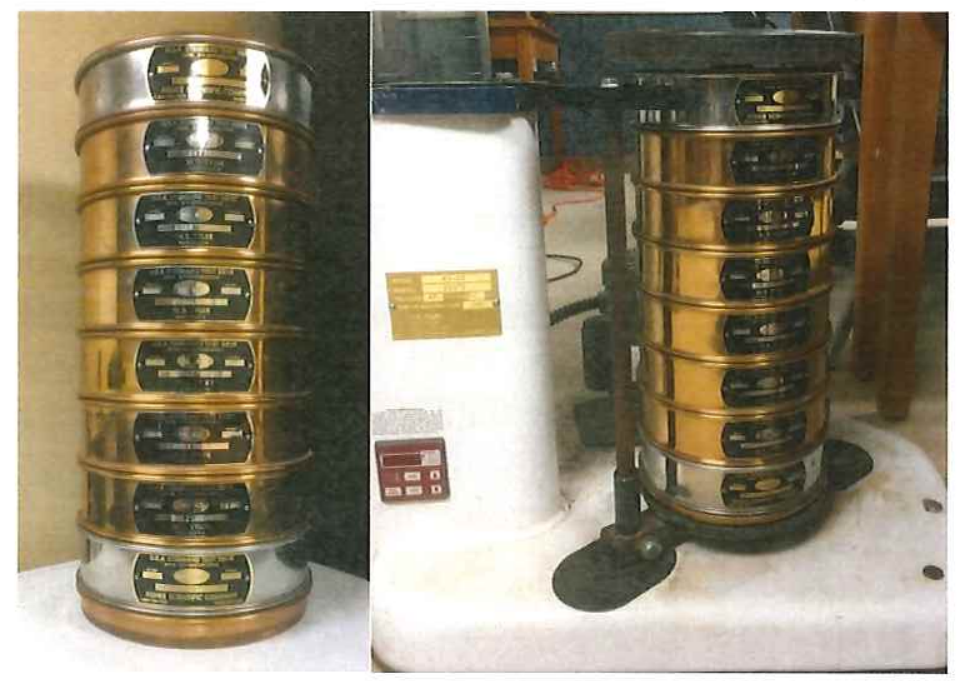

Figure 7 - All 8 sieves stacked on top of one another (left) and in the mechanical shaker (right).

Once the sieving was complete, the grains in each sieve were weighed and recorded and the percent retained and percent passing was calculated for each sieve. The weight in each sieve was divided by the total weight of material and multiplied by 100 to calculate percent retained. The percent retained in each sieve was then summed to calculate cumulative percent retained, and subtracted from 100 in each sieve to calculate percent passing.

The hydraulic conductivity and uniformity coefficient (coefficient related to size distribution of granular material) were calculated using $\mathrm{D}_{10}, \mathrm{D}_{30}, \mathrm{D}_{50}$, and $\mathrm{D}_{60}$. These values correspond to the percent of grains passing through each sieve. For example, $\mathrm{D}_{10}$ 
is equal to the amount of particles for which $10 \%$ of the material is finer in size, $\mathrm{D}_{30}$ is equal to the amount of particles for which $30 \%$ of the material is finer in size, and so on. These values were then graphed based on the sieve sizes and the percent that passed through. The $\mathrm{D}_{10}, \mathrm{D}_{30}, \mathrm{D}_{50}$, and $\mathrm{D}_{60}$ values were extrapolated from the graphs, and the hydraulic conductivity was found using three different equations. The Hazen's equation (West, 2010) is

$$
K \frac{\mathrm{cm}}{\mathrm{S}}=100\left(D_{10}\right)^{2}
$$

where $D_{10}$ is as described above. This equation works best when $D_{10}$ falls between 0.1 $\mathrm{mm}$ and $3 \mathrm{~mm}$. The Alyamani \& Sen equation (Alyamani M.S. \& Sen Z, 1993) is

$$
K=1300\left[I_{0}+0.025\left(D_{50}-D_{10}\right)\right]^{2}
$$

where $\mathrm{K}=$ hydraulic conductivity in $\mathrm{m} / \mathrm{day}, \mathrm{I}_{0}=$ intercept of the line passing through $\mathrm{D}_{10}$ and $\mathrm{D}_{50}$, where $\mathrm{D}_{10}$ and $\mathrm{D}_{50}$ are as described above. This equation works best for welldistributed samples. The Slichter equation (Slichter, C.S., 1899) is

$$
K=0.01\left(\frac{g}{v}\right) n^{3.287} d_{10}^{2}
$$

where $\mathrm{K}=$ hydraulic conductivity, $\mathrm{g}=$ gravitational acceleration $\left(9.8 \frac{\mathrm{m}}{\mathrm{s}^{2}}\right), \mathrm{v}=$ kinematic viscosity $\left(1 \times 10^{-6} \frac{m}{s^{2}}\right), \mathrm{n}=$ void ratio $\left(\frac{\phi}{1-\phi}\right)\left(\phi=0.255\left(1+0.83^{c u}\right)\right), \mathrm{D}_{10}$ is as described above, and $C u=\frac{D_{60}}{D_{10}}$ is the uniformity coefficient (West, 2010). This equation works best when $\mathrm{D}_{10}$ falls between $0.01 \mathrm{~mm}$ and $5 \mathrm{~mm}$. 


\section{RESULTS}

\section{Bail Test Method}

The depth of the well was 8.25 meters and the initial water depth was 5.33 meters. After 6.6 liters of water were bailed from the well, the water increased to 5.69 meters. The well recovered to 5.70 meters ( 2.55 meters from bottom of well) after 22 hours and then began to drop and continued to drop until recording ceased on October 13, 2016 (Fig. 8). This unexpected result required the original data to be modeled differently to find an accurate $\mathrm{K}$ value. The data were detrended (Fig. 9) to correct the drawdown of the well based on the local drop in the water table, and the detrended data were partitioned and modeled using linear and exponential models (Fig. 10). The equations (in Fig. 10) were used to calculate $t_{37}$. A summary of the $t_{37}$ estimates can be seen in Table 1.

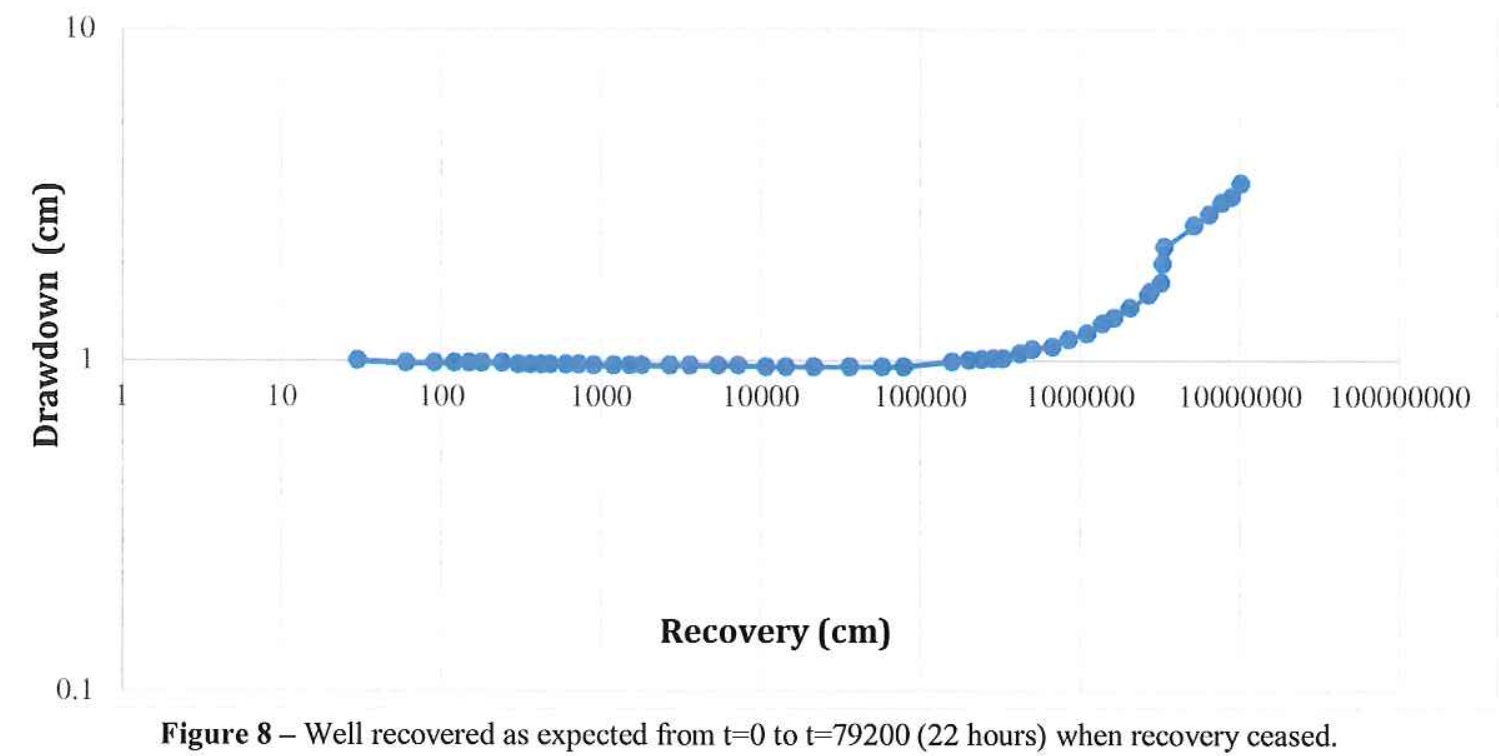




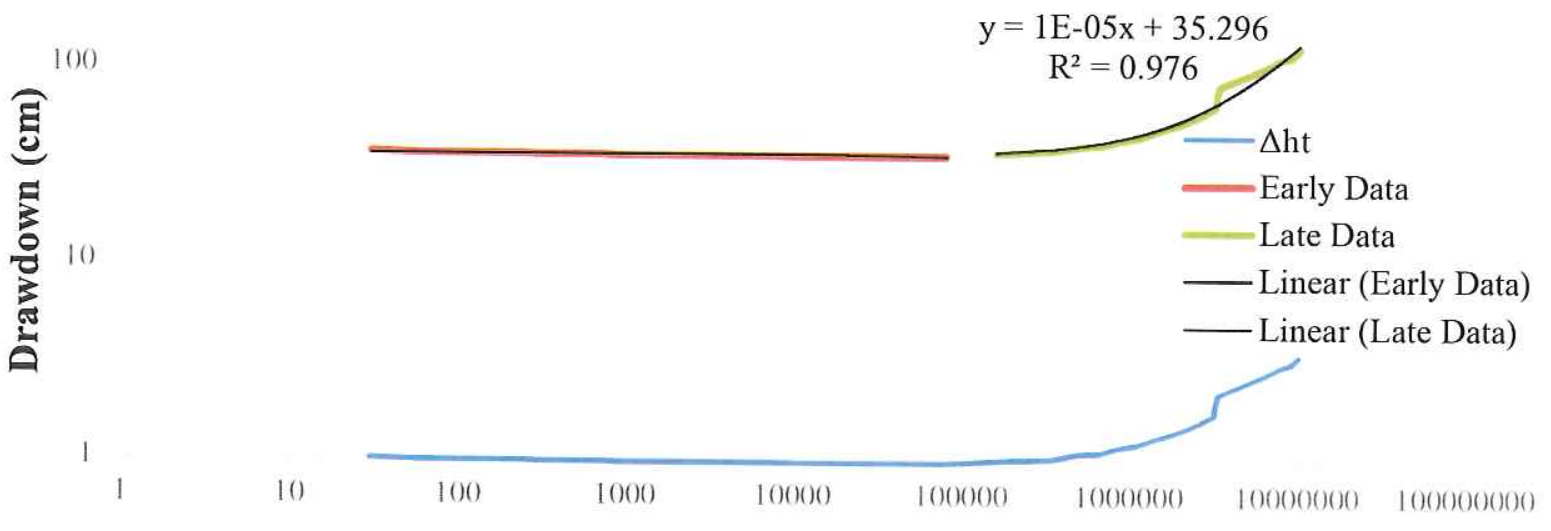

\section{Time (sec)}

0.1

Figure 9 - Water depth initially decreased during the recovery phase (0 to 22 hours). Later, water depth increased due to a local drop in the water table. Well recovery data, $\Delta \mathrm{h}_{\mathrm{t}}$ are included for comparison.

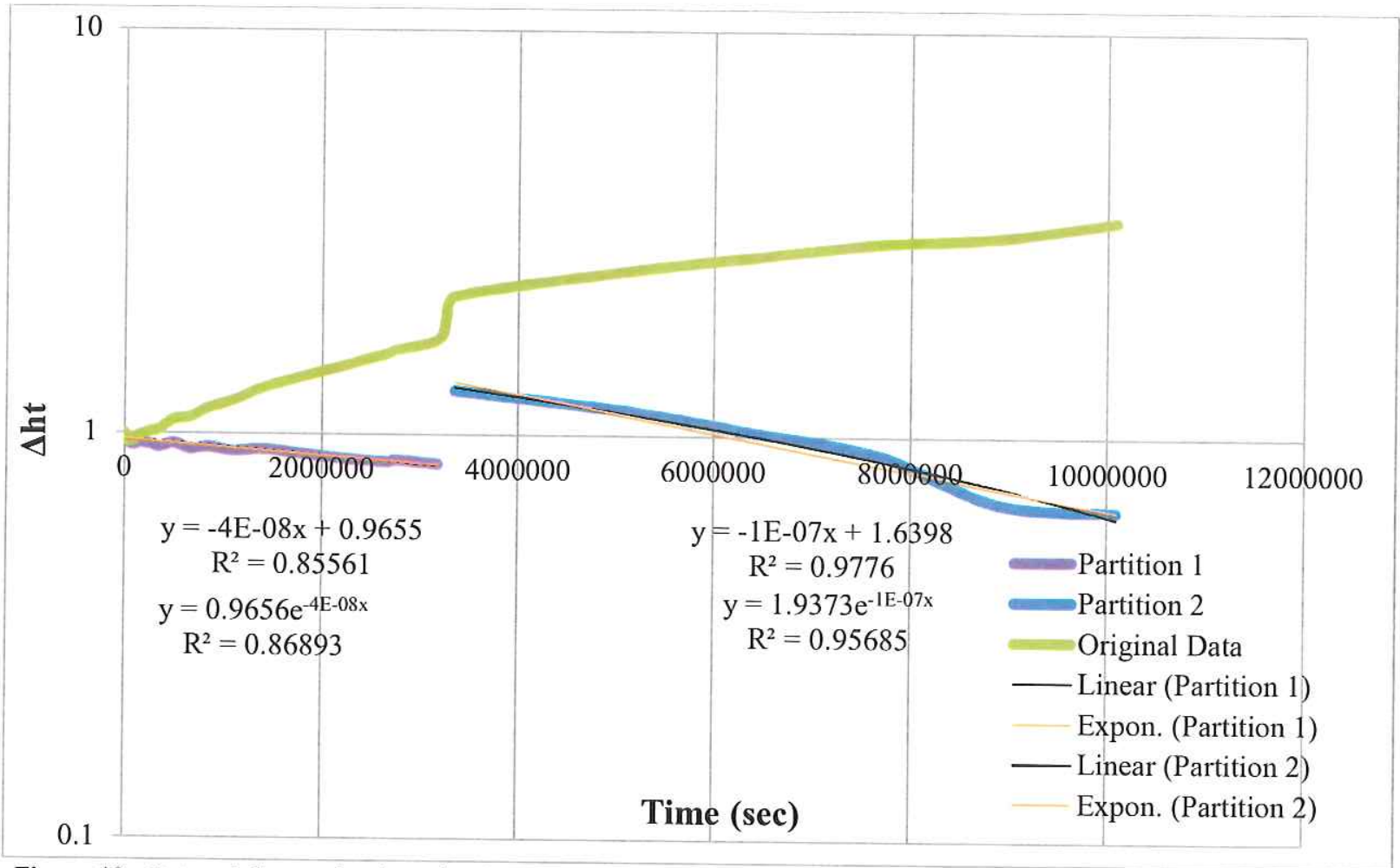

Figure 10 - Detrended water level results showing the corrected drawdown with the linear and exponential trend lines for partition 1 (in purple) and partition 2 (in blue), the original data (in green) are shown for comparison. 
Table 1 - Summary of $t_{37}$ estimates found from linear and exponential equations.

\begin{tabular}{|c|c|}
\hline \multicolumn{2}{|c|}{$\mathrm{t}_{37}$ Estimates } \\
\hline & $\mathrm{t}_{37}(\mathrm{sec})$ \\
\hline Linear Early Data & 14937500 \\
\hline Linear Late Data & 12718000 \\
\hline Exponential Early Data & 24115000 \\
\hline Exponential Late Data & 16609000 \\
\hline
\end{tabular}

The $t_{37}$ values were used to calculate $\mathrm{K}$ estimates using equations extrapolated in Figure 10. The estimates can be seen in Table 2.

Table 2 - Summary of hydraulic conductivity estimates from all bail test scenarios.

\begin{tabular}{|c|c|c|}
\hline \multicolumn{3}{|c|}{ Hydraulic Conductivity of Bail Test Estimate } \\
\hline & $\begin{array}{c}\text { K Value Assuming Well is } \\
\text { Screened Entire Length } \\
(\mathrm{cm} / \mathrm{sec})\end{array}$ & $\begin{array}{c}\text { K Value Assuming Well is } \\
\text { Screened from Static Level } \\
\text { Down }(\mathrm{cm} / \mathrm{sec})\end{array}$ \\
\hline Linear Early Data & $1.317 \times 10^{-8}$ & $2.878 \times 10^{-8}$ \\
\hline Linear Late Data & $1.547 \times 10^{-8}$ & $4.577 \times 10^{-8}$ \\
\hline Exponential Early Data & $8.158 \times 10^{-9}$ & $1.783 \times 10^{-8}$ \\
\hline Exponential Late Data & $1.185 \times 10^{-8}$ & $3.505 \times 10^{-8}$ \\
\hline
\end{tabular}

\section{Permeameter Test}

The results of the constant head permeameter test varied with depth and location of the samples. At all site locations K decreased with sample depth. Locations near the well had a lower $\mathrm{K}$ value than those by the stream at the same depths. The highest $\mathrm{K}$ value was $3.21 \times 10^{-2} \mathrm{~cm} / \mathrm{sec}$ located at Site 3 at a depth of 0 to $12.70 \mathrm{~cm}$. The lowest $\mathrm{K}$ value was $1.52 \times 10^{-6} \mathrm{~cm} / \mathrm{sec}$ located at Site 1 at a depth of 101.60 to $121.92 \mathrm{~cm}$. The full results can be seen in Table 3. Sample 3.13 was skipped because sample volume was insufficient. 
Table 3 - Hydraulic conductivity estimates calculated using permeameter method

\begin{tabular}{|c|c|c|c|}
\hline Site & Sample $\#$ & Depth $(\mathrm{cm})$ & Hydraulic Conductivity $(\mathrm{cm} / \mathrm{sec})$ \\
\hline \multirow{4}{*}{1} & 1.1 to 1.3 & $0-12.70$ & $2.092 \times 10^{-3}$ \\
\cline { 2 - 4 } & 1.4 to 1.6 & 12.70 to 25.4 & $2.059 \times 10^{-3}$ \\
\cline { 2 - 4 } & 1.7 to 1.10 & 25.4 to 40.64 & $8.853 \times 10^{-5}$ \\
\cline { 2 - 4 } & 1.11 to 1.16 & 40.64 to 60.96 & $2.018 \times 10^{-5}$ \\
\cline { 2 - 4 } & 1.17 to 1.19 & 60.96 to 68.58 & $1.899 \times 10^{-5}$ \\
\cline { 2 - 4 } & 1.20 to 1.22 & 68.58 to 76.20 & $1.719 \times 10^{-5}$ \\
\cline { 2 - 4 } & 1.23 to 1.26 & 76.20 to 87.63 & $1.247 \times 10^{-5}$ \\
\cline { 2 - 4 } & 1.27 to 1.29 & 87.63 to 97.79 & $9.521 \times 10^{-6}$ \\
\cline { 2 - 4 } & 1.30 to 1.32 & 97.79 to 101.60 & $3.233 \times 10^{-6}$ \\
\cline { 2 - 4 } & 1.33 to 1.38 & 101.60 to 121.92 & $1.519 \times 10^{-6}$ \\
\cline { 2 - 4 } 2 & 1.39 to 1.42 & 121.92 to 134.62 & $1.879 \times 10^{-5}$ \\
\hline 2 & 2.1 to 2.4 & 0 to 12.70 & $3.091 \times 10^{-5}$ \\
\hline \multirow{4}{*}{3} & 3.1 to 3.3 & 0 to 12.70 & $3.209 \times 10^{-2}$ \\
\cline { 2 - 4 } & 3.4 to 3.8 & 12.70 to 28.70 & $1.168 \times 10^{-3}$ \\
\cline { 2 - 4 } & 3.9 to 3.12 & 28.70 to 45.21 & $8.299 \times 10^{-4}$ \\
\cline { 2 - 4 } & 3.13 & 45.21 to 47.75 & Insufficient Sample Size \\
\cline { 2 - 4 } & 3.14 to 3.17 & 47.75 to 64.77 & $6.715 \times 10^{-4}$ \\
\cline { 2 - 4 } & 3.18 to 3.21 & 64.77 to 74.93 & $3.335 \times 10^{-4}$ \\
\hline \multirow{3}{*}{4} & 4.1 to 4.4 & 0 to 21.59 & $1.596 \times 10^{-3}$ \\
\cline { 2 - 4 } & 4.5 to 4.10 & 21.59 to 38.10 & $1.280 \times 10^{-4}$ \\
\hline 5 & 5.1 to 5.4 & 0 to 21.59 & $1.754 \times 10^{-3}$ \\
\hline
\end{tabular}

\section{Grain Size Distribution}

The results of the grain size distribution curves (Figures 11 - 15) showed that all the samples were well distributed containing a range of sizes and had a good representation of all sizes. The majority of grain sizes from all the site locations varied from coarse sand to fine particles. K estimates when using the Hazen equation reported higher $\mathrm{K}$ values than the permeameter test. The Hazen Method is a quick and easy way to calculate K but tends to overestimate (Cheong et al. (2008), Rosas, Jadoon, \& Missimer (2014), Svensson (2014), Takounjou, et al. (2012), Vienken and Dietrich (2005)). The 
Slichter equation underestimated K values compared to permeameter test results. The Alyamani \& Sen equation provided $\mathrm{K}$ values that best correlated to the permeameter test results. Sample 3.13 from Site 3 was skipped due to insufficient sample size. The calculated $\mathrm{K}$ values using all three equations are presented in Table 4.

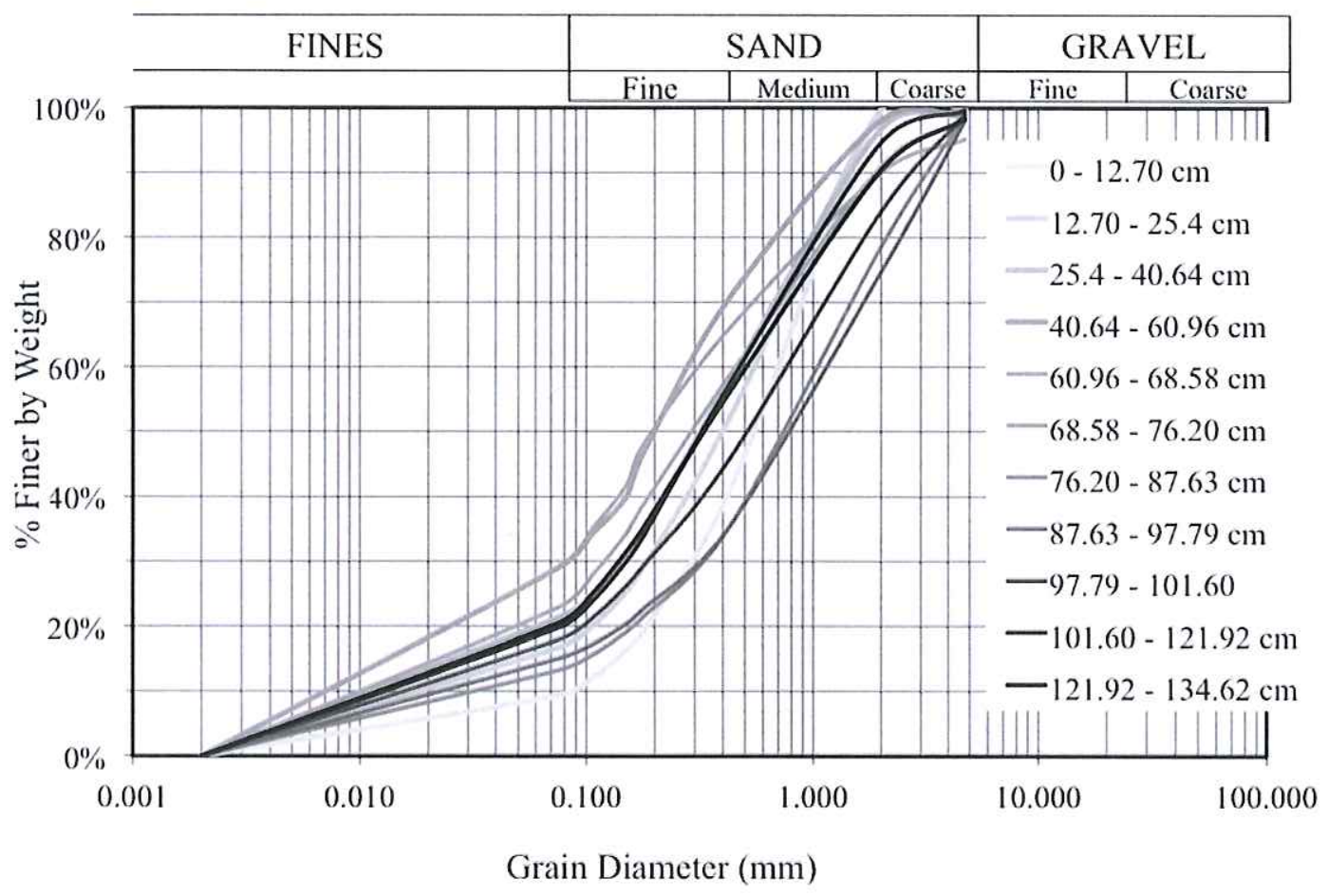

Figure 11 - Grain Size Distribution curves of each sample from Site 1. 


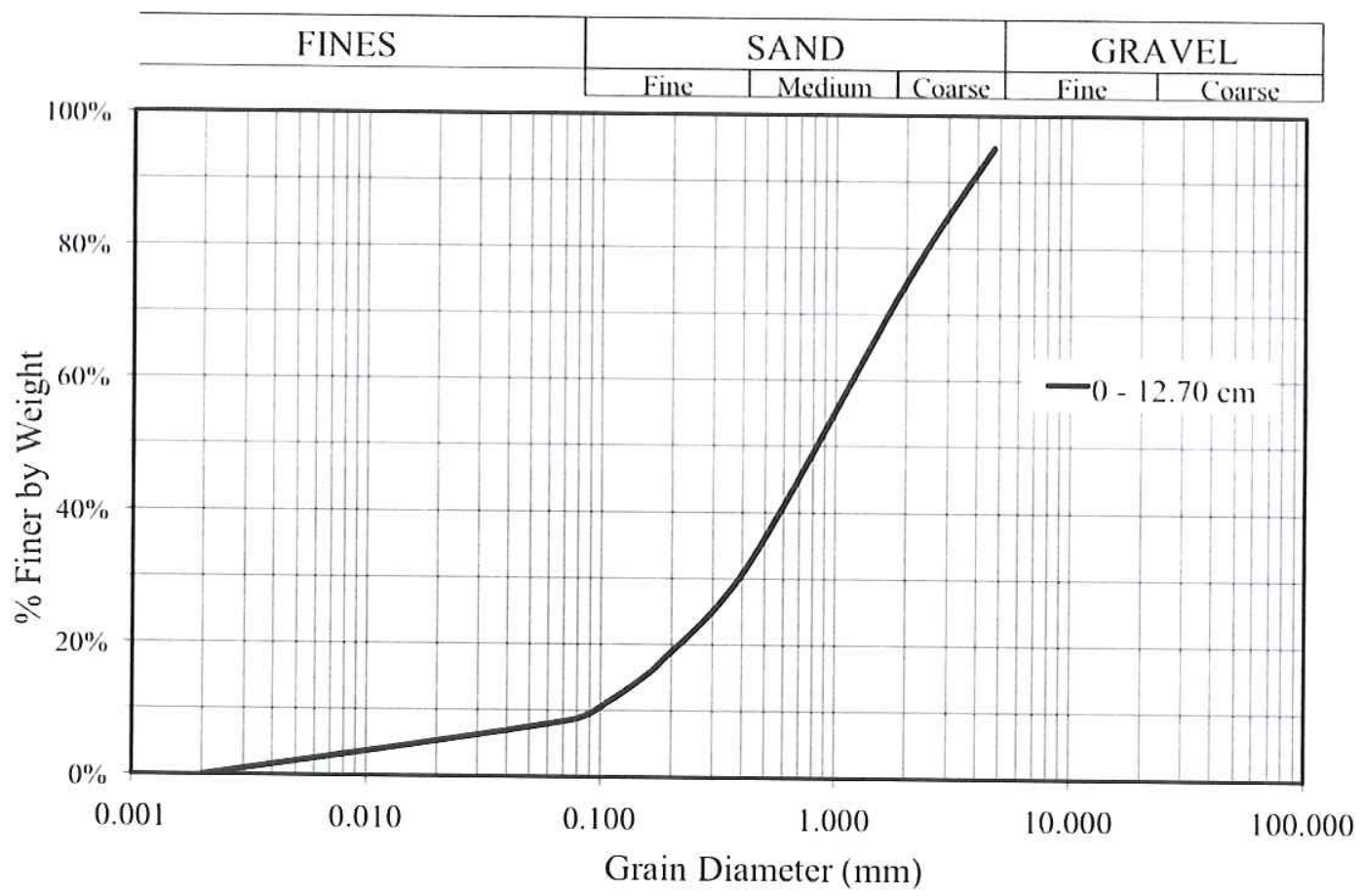

Figure 12 - Grain Size Distribution curves of each sample from Site 2.

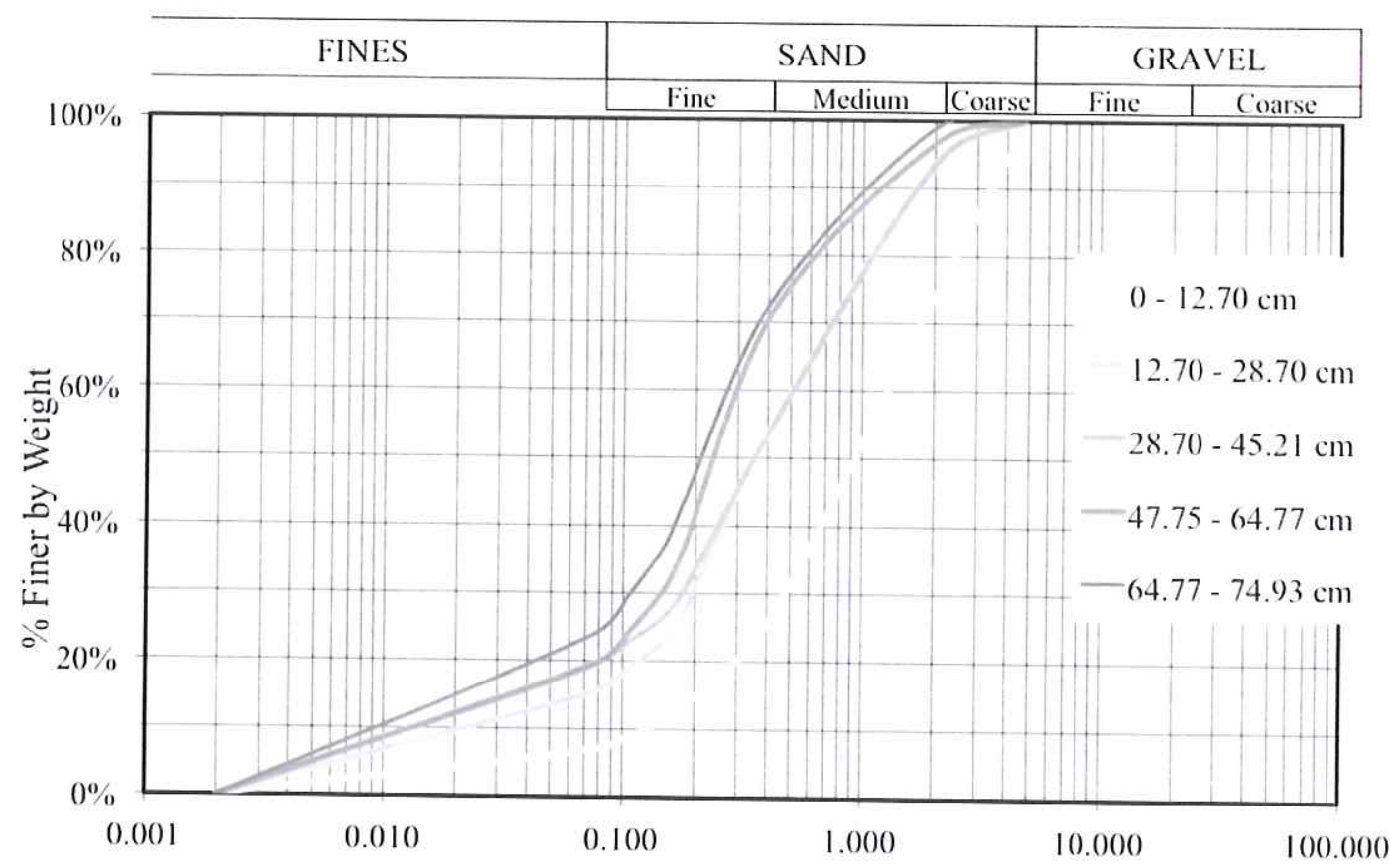

Grain Diameter (mm)

Figure 13 - Grain Size Distribution curves of each sample from Site 3. 


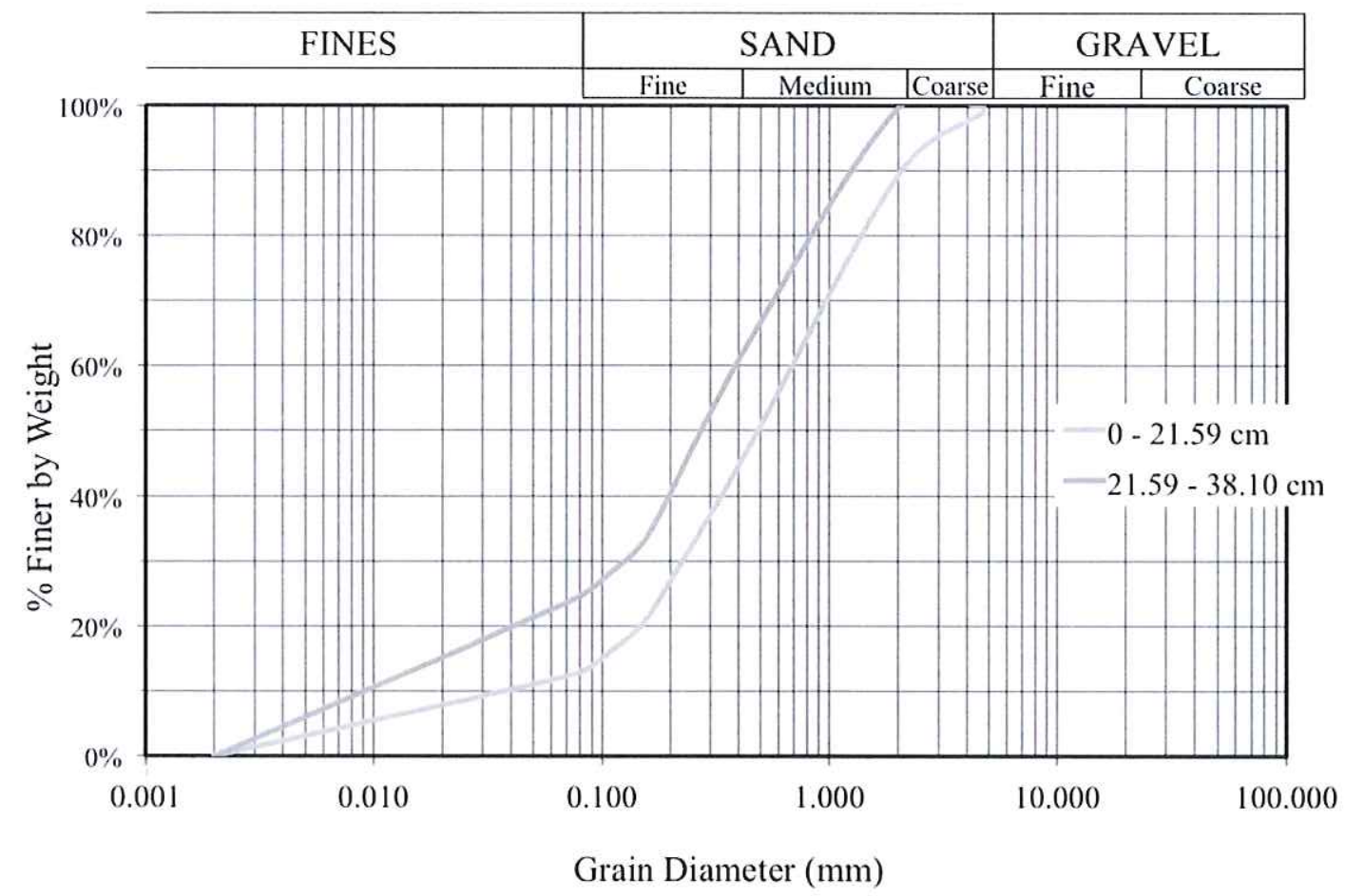

Figure 14 - Grain Size Distribution curves of each sample from Site 4.

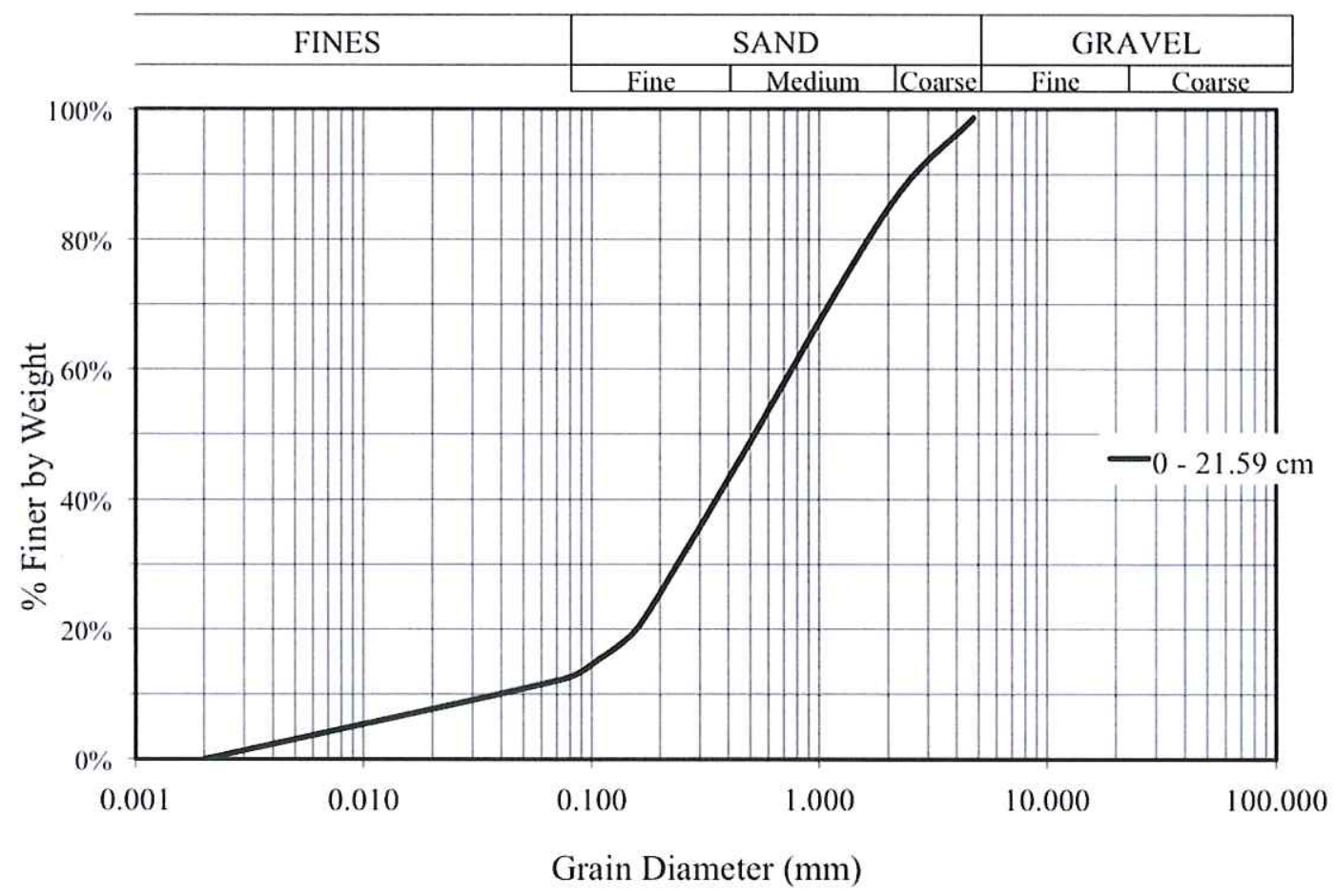

Figure 15 - Grain Size Distribution curves of each sample from Site 5. 
Table 4 - Summary of results of all methods

\begin{tabular}{|c|c|c|c|c|c|c|}
\hline Site & Sample \# & Depth $(\mathrm{cm})$ & $\begin{array}{l}\text { Permeameter } \\
\text { Method } \\
(\mathrm{cm} / \mathrm{sec})\end{array}$ & $\begin{array}{l}\text { Hazen } \\
\text { Method } \\
(\mathrm{cm} / \mathrm{sec})\end{array}$ & $\begin{array}{l}\text { Alyamani \& } \\
\text { Sen Method } \\
(\mathrm{cm} / \mathrm{sec})\end{array}$ & $\begin{array}{l}\text { Slichter } \\
\text { Method } \\
(\mathrm{cm} / \mathrm{sec})\end{array}$ \\
\hline \multirow{11}{*}{1} & $1.1-1.3$ & $0-12.70$ & $2.092 \times 10^{-3}$ & $7.225 \times 10^{-1}$ & $7.689 \times 10^{-3}$ & $6.163 \times 10^{-1}$ \\
\hline & $1.4-1.6$ & $12.70-25.4$ & $2.059 \times 10^{-3}$ & $3.240 \times 10^{-2}$ & $5.176 \times 10^{-4}$ & $9.500 \times 10^{-3}$ \\
\hline & $1.7-1.10$ & $25.4-40.64$ & $8.853 \times 10^{-5}$ & $1.440 \times 10^{-2}$ & $2.711 \times 10^{4}$ & $4.904 \times 10^{-3}$ \\
\hline & $1.11-1.16$ & $40.64-60.96$ & $2.018 \times 10^{-5}$ & $4.900 \times 10^{-3}$ & $9.680 \times 10^{-5}$ & $1.462 \times 10^{-3}$ \\
\hline & $1.17-1.19$ & $60.96-68.58$ & $1.899 \times 10^{-5}$ & $1.000 \times 10^{-2}$ & $1.989 \times 10^{-4}$ & $2.892 \times 10^{-3}$ \\
\hline & $1.20-1.22$ & $68.58-76.20$ & $1.719 \times 10^{-5}$ & $4.900 \times 10^{-3}$ & $8.860 \times 10^{-5}$ & $1.417 \times 10^{-3}$ \\
\hline & $1.23-1.26$ & $76.20-87.63$ & $1.247 \times 10^{-5}$ & $1.089 \times 10^{-1}$ & $1.678 \times 10^{-3}$ & $3.375 \times 10^{-2}$ \\
\hline & $1.27-1.29$ & $87.63-97.79$ & $9.521 \times 10^{-6}$ & $5.760 \times 10^{-2}$ & $1.254 \times 10^{-3}$ & $1.806 \times 10^{-2}$ \\
\hline & $1.30-1.32$ & $97.79-101.60$ & $3.233 \times 10^{-6}$ & $2.890 \times 10^{-2}$ & $5.204 \times 10^{4}$ & $7.399 \times 10^{-3}$ \\
\hline & $1.33-1.38$ & $101.60-121.92$ & $1.519 \times 10^{-6}$ & $1.690 \times 10^{-2}$ & $6.935 \times 10^{-3}$ & $5.695 \times 10^{-3}$ \\
\hline & $1.39-1.42$ & $121.92-134.62$ & $1.879 \times 10^{-5}$ & $1.440 \times 10^{-2}$ & $2.721 \times 10^{-4}$ & $4.168 \times 10^{-3}$ \\
\hline 2 & $2.1-2.4$ & $0-12.70$ & $3.091 \times 10^{-5}$ & $9.025 \times 10^{-1}$ & $9.239 \times 10^{-3}$ & $3.917 \times 10^{-1}$ \\
\hline \multirow{6}{*}{3} & $3.1-3.3$ & $0-12.70$ & $3.209 \times 10^{-2}$ & $1.690 \times 10$ & $1.011 \times 10$ & $8.629 \times 10^{-1}$ \\
\hline & $3.4-3.8$ & $12.7-28.70$ & $1.168 \times 10^{-3}$ & $4.840 \times 10^{-2}$ & $6.275 \times 10^{4}$ & $1.649 \times 10^{-2}$ \\
\hline & $3.9-3.12$ & $28.70-45.21$ & $8.299 \times 10^{-4}$ & $1.960 \times 10^{-2}$ & $3.250 \times 10^{-4}$ & $5.757 \times 10^{-3}$ \\
\hline & 3.13 & $45.21-47.75$ & \multicolumn{4}{|c|}{ Insufficient Sample Size } \\
\hline & $3.14-3.17$ & $47.75-64.77$ & $6.715 \times 10^{-4}$ & $2.250 \times 10^{-2}$ & $2.397 \times 10^{-4}$ & $7.222 \times 10^{-3}$ \\
\hline & $3.18-3.21$ & $64.77-74.93$ & $3.335 \times 10^{-4}$ & $1.000 \times 10^{-2}$ & $1.489 \times 10^{-4}$ & $2.991 \times 10^{-3}$ \\
\hline \multirow{2}{*}{4} & $4.1-4.4$ & $0-21.59$ & $1.596 \times 10^{-3}$ & $1.600 \times 10^{-1}$ & $1.663 \times 10^{-3}$ & $5.463 \times 10^{-2}$ \\
\hline & $4.5-4.10$ & $21.59-38.10$ & $1.280 \times 10^{-4}$ & $8.100 \times 10^{-3}$ & $1.393 \times 10^{-4}$ & $2.343 \times 10^{-3}$ \\
\hline 5 & $5.1-5.4$ & $0-21.59$ & $1.754 \times 10^{-3}$ & $1.600 \times 10^{-1}$ & $1.739 \times 10^{-3}$ & $5.217 \times 10^{-2}$ \\
\hline \multicolumn{7}{|c|}{ Bail Method $(\mathrm{cm} / \mathrm{sec})$} \\
\hline & & \multicolumn{2}{|c|}{$\begin{array}{l}\text { K from screen measured at } \\
\text { entire well length }\end{array}$} & \multicolumn{3}{|c|}{$\begin{array}{l}\text { K from screen measured from static water } \\
\text { length to bottom of well length: }\end{array}$} \\
\hline \multicolumn{2}{|c|}{$\begin{array}{l}\text { Linear Early } \\
\text { Data }\end{array}$} & \multicolumn{2}{|c|}{$1.317 \times 10^{-8}$} & \multicolumn{3}{|c|}{$2.878 \times 10^{-8}$} \\
\hline \multicolumn{2}{|c|}{ Linear Late Data } & \multicolumn{2}{|c|}{$1.547 \times 10^{-8}$} & \multicolumn{3}{|c|}{$4.577 \times 10^{-8}$} \\
\hline \multicolumn{2}{|c|}{$\begin{array}{l}\text { Exponential } \\
\text { Early Data }\end{array}$} & \multicolumn{2}{|c|}{$8.158 \times 10^{-9}$} & \multicolumn{3}{|c|}{$1.783 \times 10^{-8}$} \\
\hline \multicolumn{2}{|c|}{$\begin{array}{l}\text { Exponential Late } \\
\text { Data }\end{array}$} & \multicolumn{2}{|c|}{$1.185 \times 10^{-8}$} & \multicolumn{3}{|c|}{$3.505 \times 10^{-8}$} \\
\hline
\end{tabular}




\section{DISCUSSION}

\section{Changes in $\mathrm{K}$ with Depth}

The permeameter test provided results most similar to the well bail test results at depths of 101.60 to $134.60 \mathrm{~cm}$. The well may also be surrounded by or on top of bedrock that would provide a lower $\mathrm{K}$ value than at shallow depths. The three grain size distribution methods provided results that were similar, but the Hazen Method produced higher $\mathrm{K}$ values ranging from $8.10 \times 10^{-3}$ to $1.09 \times 10^{-1} \mathrm{~cm} / \mathrm{sec}$. This method is a quicker and less reliable method than a well test or the permeameter method (Cheong et al. (2008), Rosas, Jadoon, \& Missimer (2014), Svensson (2014), Takounjou, et al. (2012), Vienken and Dietrich (2005)). The Alyamani \& Sen method provided the lowest K values of the three different grain size distribution methods. This is partly because this method is most appropriate for well distributed samples and the samples collected from the study area were well distributed. The well bail test results provided lower $\mathrm{K}$ values because it represents a $\mathrm{K}$ value of soil (or rock) from deeper horizons reaching a depth of $532.79 \mathrm{~cm}$ while the other $\mathrm{K}$ values were estimated for depths of $134.62 \mathrm{~cm}$ at most.

\section{Water Table Fluctuation}

The well bail test provided unexpected results due to a drop in the local water table. This drop in the water table most likely occurred because of a drought that occurred during the study period. At the start of the well bail test (May, 2016), the eastern portion of Tennessee was classified as "Abnormally Dry" to "Moderate Drought". By the end of the test (October, 2016), drought was present across the state, with the most severe levels in southeastern Tennessee (Fig. 16). 
Drought Severity
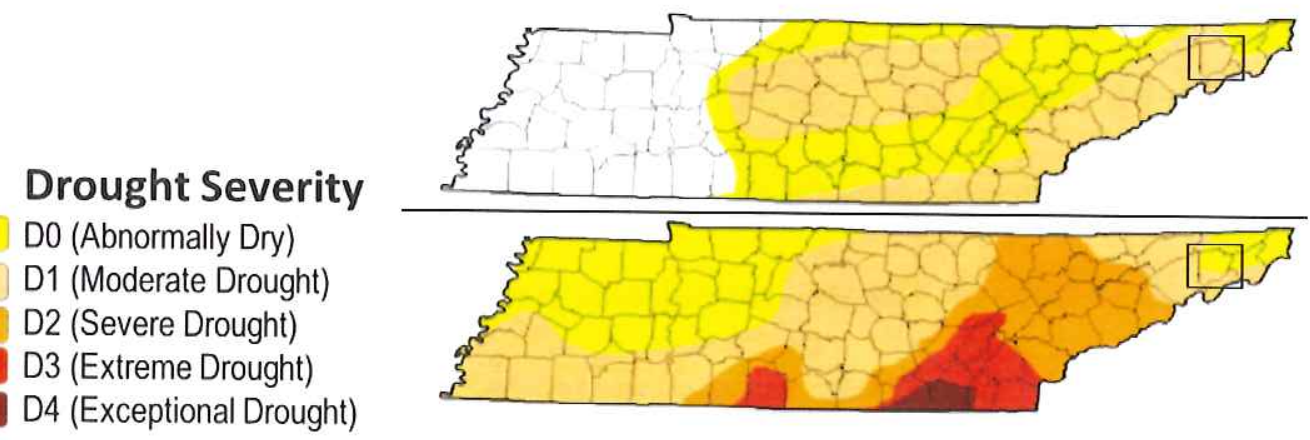

Figure 16 - Map of Tennessee showing the severity of the drought on May 17, 2016 (top) and October 25, 2016 (bottom); Washington County is outlined in a black box.

In Washington County, TN, while the drought was not as severe as in the counties to the south, drought onset occurred at the start of the well bail test, and continued through the test (Fig. 17).

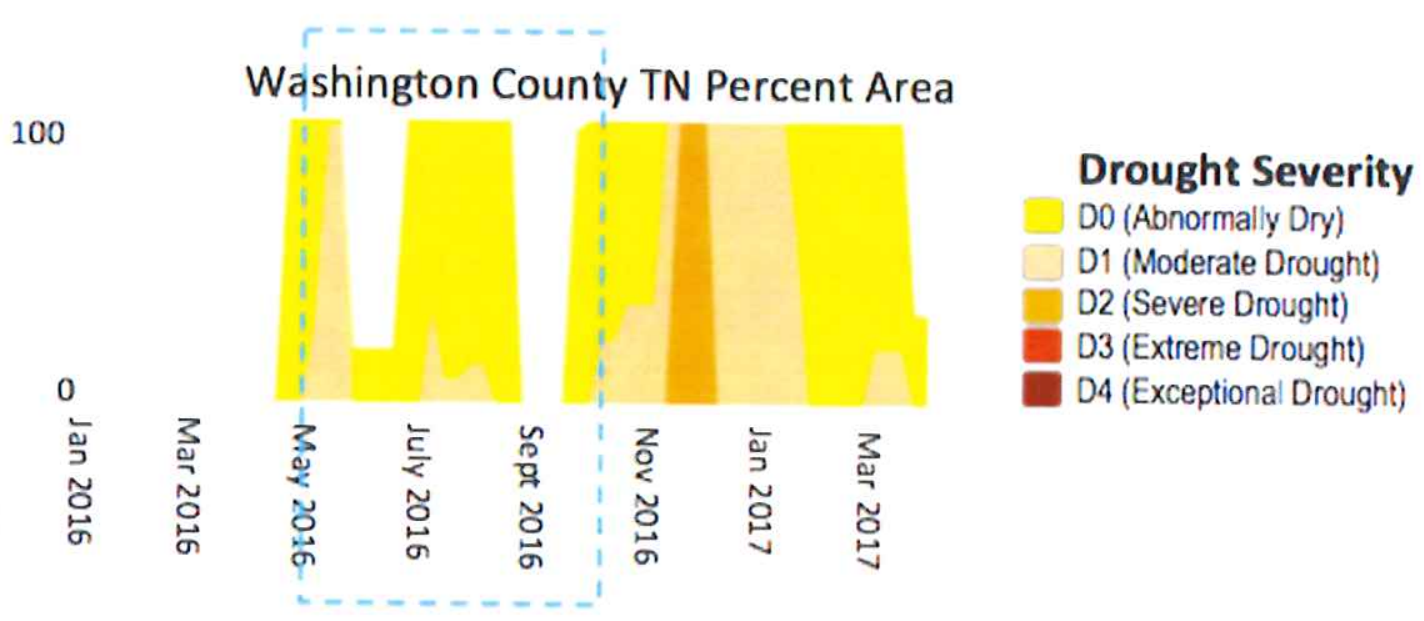

Figure 17 - Local drought severity for Washington County, TN shown by month indicates abnormally dry to moderate drought conditions during the well bail test study period (outlined with the dashed box).

\section{Changes in $\mathrm{K}$ with Site Location}

The sites near the well and by the stream provided different $\mathrm{K}$ values for the permeameter and grain size distribution methods, due to soil composition differences at the two sites. The site near the well had clay rich soil with a low K value. In contrast, the 
sites near the stream had sandy, loamy soil typical of a flood plain setting. The USDA values of the $\mathrm{BmC}$ soil have a $\mathrm{K}$ value of $7.84 \times 10^{-4} \mathrm{~cm} / \mathrm{sec}$ and the $\mathrm{CeD} 3$ soil have a $\mathrm{K}$ value of $2.82 \times 10^{-4} \mathrm{~cm} / \mathrm{sec}$ (USDA Soil Survey, 2016). These two soil types are located near the well where the samples were collected. This value is similar to $\mathrm{K}$ estimates obtained using the constant head permeameter test and to the Alyamani \& Sen method at this site, but values obtained using the Hazen and Slichter methods resulted in higher K estimates.

The USDA values of the St soil near the stream report a K value of $8.29 \times 10^{-4}$ $\mathrm{cm} / \mathrm{sec}$ (USDA Soil Survey, 2016). This value is close to those found with the constant head permeameter, Alyamani \& Sen, and Slichter methods. The Hazen method provided higher $\mathrm{K}$ values all around and is known to overestimate. The shallow samples provided K values that were similar to those found by Nandi and Luffman (2012) at the area near the well.

\section{Comparison of Methods}

The results from the three methods for calculating $\mathrm{K}$ values vary depending on depth and location of the soil samples. The $\mathrm{K}$ values at sites near the well are slightly lower than values found near the blue line stream. The results of the different tests varied in magnitude from $10^{-1}$ to $10^{-9}$. The well bail test provided the lowest $\mathrm{K}$ value because it was the only test conducted in deeper soils or rock. The permeameter results gave a lower magnitude of $10^{-6}$ at the lowest depths, which agrees with the bail test. The grain size distribution methods provided varied results between the three different equations. Holding the ASTM (American Standards for Testing Materials) based Constant Head Permeameter Test as the accepted standard test we conclude that the Alyamani \& Sen 
method provides comparable results to the permeameter test with less labor and using more readily available lab equipment. This suggests that the Alyamani \& Sen method may be a good substitute for the permeameter test in similar soils. Comparing these estimates helps to better understand the difference between various field and laboratory methods to compute the hydraulic conductivity.

\section{CONCLUSION}

The comparison of the $\mathrm{K}$ estimates from the utilized field and lab methods has provided insight on how the methods differ and relate to each other. The Alyamani \& Sen, Slichter, and permeameter methods produced similar K values ranging from $9.52 \mathrm{x}$ $10^{-6}$ to $1.25 \times 10^{-3} \mathrm{~cm} / \mathrm{sec}$. These are similar to the USDA K values ranging from $9.17 \mathrm{x}$ $10^{-4}$ to $2.82 \times 10^{-4} \mathrm{~cm} / \mathrm{sec}$. The Hazen method overestimated $\mathrm{K}$ and ranged from $8.10 \mathrm{x}$ $10^{-3}$ to $1.09 \times 10^{-1} \mathrm{~cm} / \mathrm{sec}$. The well bail test yielded a lower $\mathrm{K}$ value (ranging from $8.16 \mathrm{x}$ $10^{-9}$ to $1.19 \times 10^{-8} \mathrm{~cm} / \mathrm{sec}$ ) than the USDA values as expected for water flow in deeper soil horizons at a depth of 8.50 meters. If the samples are from shallow depths and are well distributed, the Alyamani \& Sen GSD method is recommended over other equations. If there are time constraints present, the Alyamani \& Sen GSD method can be used over more time consuming methods. This research identified regional hydrologic variability; the drier summer may have influenced these processes however, further study is required to explore the relationship between water table fluctuations and precipitation. 


\section{ACKNOWLEDGEMENTS}

This project was made possible by the Summer Research Fellowship funding provided by the ETSU Honors College and the help of field assistants Jamie Kincheloe, Cameron Maddux, and Nick McConnell.

\section{REFERENCES}

Alyamani M. S. \& Sen Z. (1993). Determination of hydraulic conductivity from complete grain-size distribution. Ground Water, 31(4), 551-555.

Barua, G., \& Hoffmann, M. R., (2007). Theory of seepage into an auger hole in a confined aquifer overlying a gravel substratum. Journal of Irrigation and Drainage Engineering, July/August 2007, 330-339.

Cheong, J.-Y.et al., (2008). Estimating hydraulic conductivity using grain-size analyses, aquifer tests, and numerical modeling in a riverside alluvial system in South Korea. Hydrogeology Journal, Volume 16, pp. 1129-1143.

Fetter, C.W., (2001). Applied Hydrology. Upper Saddle River, NJ: Prentice Hall.

Hardeman, William D. (1966) Geologic Map of Tennessee (map). (ca. 1:250,000). Tennessee, Division of Geology.

Hvorslev, M. J. (1951). Time lag and soil permeability in ground-water observations. Vicksburg, MS: Waterways Experiment Station, Corps of Engineers, U.S. Army.

King, Philip B. \& Ferguson, Herman W. (1960). Geology of Northeastermost Tennessee. (Professional Paper). (Washington, DC). United States Government Printing Office. 
Molen, W. H., Beltrán, J. M., \& Ochs, W. J. (2007). Guidelines and computer programs for the planning and design of land drainage systems. Rome: Food and Agriculture Organization of the United Nations.

Munsell Color (Firm). (2009). Munsell soil color charts: with genuine Munsell color chips. Grand Rapids, MI :Munsell Color.

Nandi, Arpita, \& Luffman, Ingrid (2012). Erosion related changes to physicochemical properties of ultisols distributed on calcareous sedimentary rocks. Journal of Sustainable Development, 5 (8) 52-68.

Rosas, J., Jadoon, K. Z., Missimer, T.M., (2014). New empirical relationship between grain size distribution and hydraulic conductivity for ephemeral streambed sediments. Environ Earth Sci, 73, 1303-1315.

Rodgers, John (1953) Geologic Map of East Tennessee with Explanatory Text. (Bulletin 58, Part 2). (Nashville, Tennessee) United States Geological Survey and the Tennessee Division of Geology.

Schoeneberger, P.J., D.A. Wysocki, E.C. Benham, and Soil Survey Staff. (2012). Field book for describing and sampling soils, Version 3.0. Natural Resources Conservation Service, National Soil Survey Center, Lincoln, NE.

Slichter, CS (1899) Theoretical investigation of the motion of ground waters. US Geological Survey 19th Annual Report, Part 2, p 322

Svensson, Andrea, (2014). Estimation of hydraulic conductivity from grain size analyses: A comparative study of different sampling and calculation methods focusing on Vastlanken. (Master's Thesis). Department of Civil and Environmental Engineering. 
Takounjou, A. F., Fantong, W., Ngoupayou, J. N., \& Nkamdjou, L. S., (2012).

Comaparative analysis for estimating hydraulic conductivity values to improve the estimation of groundwater recharge in Yaounde-Cameroon. British Journal of Environment \& Climate Change, 2(4), 341-409.

van Beers, W.F. J., (1983). The Auger Hole Method: A Field Measurement of the Hydraulic Conductivity of Soil Below the Water Table. Netherlands: ILRI.

Vienken, T. \& Dietrich, P., 2011. Field evaluation of methods for determining hydraulic conductivity from grain size data. Journal of Hydrology, Volume 400, pp. 58-71.

USDA Web Soil Survey, 2016. Web Soil Survey. In: ServiceN.R.C. (Ed.).

West, L. T., Abreu, M.A., \& Bishop, J.P., (2007) Saturated hydraulic conductivity of soils in the Southern Piedmont of Georgia, USA: Field evaluation and relation to horizon and landscape properties. Catena, 73, 174-179.

West, Terry R., (2010) Geology Applied to Engineering. Waveland Press Inc. 
